\title{
LA ESTELA DEL POLIFEMO O EL FLORECIMIENTO DE LA FÁBULA BARROCA (1613-1624) ${ }^{1}$
}

\author{
Mercedes Blanco \\ Universidad de Paris IV-Sorbonne
}

\section{INTRODUCCIÓN. LA EMERGENCIA DE LA FÁBULA BARROCA}

La polvareda levantada por las Soledades tiende a ocultar parcialmente la fuerte impresión que provocaron por las mismas fechas "los nuevos y peregrinos modos" del Polifemo $^{2}$. Y es que el poema más reciente era también más insólito y difícil de asimilar.

1 Recibido: 30-XI-2009 Aceptado: 23-II-2010

Este artículo es la versión original de un trabajo que fue publicado en forma muy abreviada bajo el título « La estela del Polifemo » en Actas del XII Congreso de la Asociación Internacional de Hispanistas, Birmingham, 1995. Tomo II, Estudios Áureos I, ed. al cuidado de J. Whicker, The University of Birmingham, 1998, pp. 42-59. Respondiendo al amistoso deseo de los editores de publicar la versión extensa en las actas de la jornada de estudios del TIPSO, he realizado una labor de revisión y puesta al día.

2 Como escribe Melchora Romanos, en un artículo dedicado a la recepción inmediata del Polifemo sobre todo a través de las anotaciones de Díaz de Ribas: « En la gran conmoción producida por la difusión de las Soledades, en la primavera de 1613, la Fábula de Polifemo y Galatea, que acompañaba en 
Razón por la cual si buscamos los efectos, en los sucesores de Góngora, no ya del estilo de las Soledades, sino del poema en su configuración total, éstos aparecen dispersos entre varios géneros y durante un largo período. Quizá por ello no se ha escrito todavía la historia completa de las tentativas de escribir algo parecido a las Soledades, si bien los estudios acerca de la silva ${ }^{3}$, el cultismo ${ }^{4}$, la poesía de la "soledad", la poesía descriptiva ${ }^{5}$ y el epitalamio ${ }^{6}$ ofrecen episodios de lo que podría ser esta historia. Entre los textos precoces afines al proyecto poético de las Soledades se cuentan las largas silvas de López de Zárate, la primera de las cuáles, la Silva a la ciudad de Logroño, se imprime ya en $1619^{7}$. Pero debemos ver sin duda sus retoños más inconfundibles en ciertas silvas laberínticas que se van componiendo a lo largo del siglo XVII e incluso en el siglo siguiente, al modo del célebre Paraíso cerrado de Soto de Rojas (1652) o el no menos grandioso Primero sueño (1692) de Sor Juana. Estos ambiciosos poemas que incluyen una enciclopedia erudita, un alfabeto de símbolos, una representación del cosmos material y una metafísica del retiro del mundo, forman una corriente profunda en el océano de la poesía barroca, pero secreta o al menos confidencial.

El aspecto de la recepción gongorina del que nos vamos a ocupar tiene características del todo opuestas. Se trata de un fenómeno transitorio pero público y estruendoso, que ocupa por algún tiempo el centro del "campo literario" ${ }^{8}$, absorbiendo la atención de los poetas y de los doctos y discretos aficionados a la poesía. El Polifemo, más accesible que las Soledades como propuesta poética, parece desencadenar una boga de la fábula mitológica en los años que siguen inmediatamente a la difusión del

forma programática a la Soledad primera, no parece haber ocupado un lugar destacado en las contiendas [...] » («Los "tan nuevos y peregrinos modos" del Polifemo. Ponderación de la poética gongorina en los comentaristas del siglo XVII », Góngora Hoy VII. El « Polifemo », ed. J. Roses, Córdoba, Diputación, 2005, pp. 215-231).

3 Véase la "Bibliografía crítica sobre la silva (1941-1991)" establecida por V. Nuñez Ribera y L. Luna Gutiérrez, en La silva, ed. de B. López Bueno. Grupo de investigación "Poesía española del siglo de Oro". Universidad de Sevilla-Universidad de Córdoba, 1991, pp. 113-128.

4 Entre ellas destacan los libros de A. Egido, La poesía aragonesa del siglo XVII. Raíces culteranas, Zaragoza, Instituto Fernando el Católico, 1979, Silva de Andalucía. Estudios sobre la poesía barroca, Diputación Provincial de Málaga, 1990.

5 M. J.Woods, The Poet and the Natural Worl in the Age of Góngora. Oxford University Press, 1978.

6 Para el epitalamio en el Siglo de Oro, la tradición clásica e italiana en que se apoya y el papel de renovación que en ella desempeña Góngora, son fundamentales los trabajos de Jesús Ponce Cárdenas, su artículo «El epitalamio barroco : algunas notas sobre la narratio mítica », I. Colón Calderón y J. Ponce Cárdenas, Estudios sobre Tradición Clásica y Mitología en el siglo de Oro , Madrid, Ediciones Clásicas, 2002, pp. 83-94 y su libro Evaporar contempla un fuego helado. Género, enunciación lírica y erotismo en una canción gongorina, Málaga, Universidad de Málaga, 2006.

7 Véase M. T. González de Garay, "López de Zárate y su "Silva a Logroño" en Calle Mayor, 3, 1986, Logroño, p. 42 y ss.

8 He tratado de justificar el empleo de esta noción, tomada del sociólogo Pierre Bourdieu, para el estudio de la literatura del Siglo de Oro, en mi artículo "Poéticas, retóricas y estudio crítico de la literatura", Penser la littérature espagnole, Bulletin Hispanique, n¹-Juin 2004, p. 213-233. 
poema de Góngora, coincidente con la del poema algo anterior y de idéntico tema de Luis Carrillo, desde 1613 hasta mediados de la década de 1620. Con la expresión 'la estela del Polifemo' ciframos la hipótesis de que algunas fábulas escritas poco después de darse a conocer la fábula de Góngora deben sus propiedades y tal vez su existencia al impulso que procede de este poema. Dejaremos de lado los Polifemos y otras fábulas mitológicas a lo divino ${ }^{9}$ como también las fábulas burlescas, no sólo porque son textos más tardíos y porque sería ocioso pretender abarcar tan amplia materia en pocas páginas, sino porque no cuadran en la problemática que tratamos de plantear.

El libro de José María de Cossío, Fábulas mitológicas en España, publicado en 1952, representa el tipo de trabajo que hoy nadie escribiría, a la vez por la inmensa lectura que supone y por lo rudimentario de un método que consiste en clasificar los poemas en virtud de su mayor o menor cercanía a los polos de la supuesta claridad, representada por Lope de Vega, y la supuesta oscuridad representada por Góngora. Pero Cossío aporta observaciones nada desdeñables como la siguiente, a propósito de la Fábula de Acis y Galatea de Luis Carrillo :

Lo primero que debe notarse al tratar del poema de Carrillo es lo aparentemente anacrónico del intento, pues el prurito de componer fábulas mitológicas puede decirse que había pasado y ya iban transcurridos quince o veinte años de casi absoluta esterilidad en estos temas. ${ }^{10}$

Y a propósito del Polifemo de Góngora :

Como Sicilia ante los encantos de Galatea, ha de arder la poesía española ante el atractivo singular de este poema. ${ }^{11}$

De modo que, según Cossío, del efecto conjugado de dos poemas "polifémicos", el de Carrillo y el de Góngora, resultó una súbita fecundidad del género fábula en la poesía española del siglo XVII, un interés renovado por el tratamiento narrativo de los mitos clásicos. Ahora bien, como mostró Dámaso Alonso en un famoso artículo, el poema de Carrillo dejó escasas huellas en el de Góngora y constituyó a lo sumo un estímulo externo $^{12}$. Sin que ello suponga negar sus cualidades, su carácter de ejercicio juvenil lo hace impropio para desempeñar un papel revolucionario y marcar la orientación de la poesía de su tiempo. No parece pues justo poner en duda que fue Góngora y sólo

9 De las que se ha ocupado Antonio Cruz Casado, «Secuelas de la Fábula de Polifemo y Galatea : versiones barrocas a lo burlesco y a lo divino », Criticón, 49, 1990 ; pp. 51-59 y « El Polifemo a lo divino (Salamanca, 1666) de Martín de Páramo y Pardo : deudas gongorinas », Góngora Hoy VII. El Polifemo, coord. Y ed. J. Roses, Córdoba, Col. «Estudios Gongorinos », Diputación de Córdoba, 2005, pp.89-106.

10 José María de Cossío : Fábulas mitológicas en España. Madrid, Espasa, 1952, p. 303.

11 Ibid.

12 Dámaso Alonso : "La supuesta imitación por Góngora de la Fábula de Acis y Galatea” (1926) en Estudios y ensayos gongorinos, Madrid, Gredos, 1982 (1a ed. 1955), p. 324-370. Aporta nuevos datos sobre el tema Jesús Ponce Cárdenas en un trabajo reciente: "Góngora y el conde de Niebla. Las sutiles gestiones del mecenazgo", Criticón, 106 (2009), pp. 99-146 (en especial, pp. 115-117). 
él quien dio impulso al revival ovidiano que marca la poesía de las grandes décadas barrocas, los últimos años de Felipe III y los de la etapa más afortunada del ministerio de Olivares.

Sería muy útil que algún equipo de investigadores rehiciera sistemáticamente el inventario de los poemas narrativos de asunto mitológico que Cossío llevó a cabo como tarea previa a su libro. Claro que el catálogo como tal no le interesaba, le interesaba el ameno paseo por una extensa colección de poemas, como a un connaisseur el paladeo de una colección de cuadros. Este catálogo previo, no incluido como tal en el libro, se refleja en su estudio que, pese a ser poco más que una larga retahíla de bocetos impresionistas, se deja leer con placer, a causa de las frecuentes citas y de las cualidades de la redacción. Con todo, el inventario es lo bastante copioso para que parezca razonable suponer que una porción mayoritaria de los textos no perdidos que responden a la definición "fábula mitológica" se consideran en el libro, y que esta porción incluye casi todos los textos de alguna importancia estética o histórica.

Daremos pues por buena la afirmación de Cossío según la cual en los veinte años que preceden al Polifemo, la producción de poemas narrativos extensos de tema mitológico decae sensiblemente. En cambio en los veinte años que siguen a este poema, esa producción alcanza un ritmo considerable, que irá decreciendo paulatinamente hasta llegar a finales de siglo. Este descenso es paliado por la redacción de poemas mitológicos de tipo festivo, que en su forma narrativa extensa, derivan casi siempre ya de Quevedo, ya del Píramo y Tisbe de Góngora de 1618. A decir verdad, el mismo Polifemo fue varias veces objeto de imitación jocosa, costumbre inaugurada por Alonso de Castillo Solórzano a cuya Fábula de Polifemo, anterior a 1624, acaba de dedicar un interesante y concienzudo trabajo Rafael Bonilla ${ }^{13}$. Pero no tendremos en cuenta aquí esta u otras empresas de homenaje burlesco, los "donaires de las musas", sino los serios intentos de igualar o eclipsar a Góngora emulando su manera inédita de enfrentarse al mito.

No sólo el trabajo de Cossío sino otros más recientes y rigurosos nos llevan a admitir que hacia 1620 la materia mitológica en la poesía española ocupa una posición estratégica en la feria de las reputaciones literarias ${ }^{14}$. Nuestro propósito será buscar

13 Rafael Bonilla, Lacayo de risa. El Gongorismo de la Fábula de Alonso de Castillo Solórzano, Col. «Estudios gongorinos ", Córdoba, Diputación, en prensa. Debemos a la generosidad y amistad del autor el haber podido consultar este trabajo, derivado de su tesis doctoral .

14 Un importante aspecto del fenómeno ha sido estudiado por Juan Matas Caballero en su artículo « La mitología, campo de tiro en la batalla de los estilos poéticos : Jáuregui y Pérez de Montalbán » en G. Cabello Porras y J. Campos Daroca (coords.), Poéticas de la Metamorfosis. Tradición clásica, Siglo de Oro y la Modernidad, Universidad de Málaga / Universidad de Almería, 2002, pp. 283-320. Recogido ahora como capítulo V en su libro Espada del Olvido. Poesía del Siglo de Oro a la Sombra del Canon, Universidad de León, Secretariado de Publicaciones, 2005. 
las razones que explican el relativo agotamiento de esta materia como base de una narración extensa, en torno a 1600, y también su nueva fecundidad, a partir del original tratamiento que le da Góngora en el Polifemo. La cuestión sería ¿qué hace Góngora con la fábula de tipo ovidiano, con el relato de "transformaciones" que venía cultivándose desde la primera generación de los poetas italianizantes, desde Boscán, Garcilaso y Diego Hurtado de Mendoza? ¿Cómo se las arregla para transformar una vena casi agotada en un caudal abundante al que todos acuden? Esta operación exige, creemos, que se modifiquen la percepción del mito y el modo de acercarse a los textos clásicos que lo transmiten.

\section{La fábula como base de la erudición poética del Renacimiento al Barroco}

\subsection{La fábula como piedra angular de la lengua poética}

Es de sobra conocido que los mitos clásicos son una pieza fundamental de la poética de los siglos áureos, hasta el punto de que se da con frecuencia la confusión entre el mundo forjado por los poetas y el mundo de la "fábula". Así se explica que Pedro Sánchez de Viana, autor de la última de las grandes versiones españolas renacentistas de las Metamorfosis de Ovidio (Valladolid, 1589) dedique su prólogo a un elogio de la poesía, inseparable del elogio del poeta que traduce :

Luego si los poetas son divinos más que humanos, si solos ellos son los que entre todos los que escriven, comprehenden y enseñan todas las disciplinas, si son los más antiguos de todos, si de sus escriptos se espera y goza utilidad, junto a grandíssimo contentamiento y reglas infinitas de bien dezir y bien vivir, confirmados con dulcissimos exemplos, devriamos con ardentissimo estudio y summa industria, dar nos al conocimiento dellos [...] Entre todos los quales haze raya el Ovidio en la presente obra, cuya poesia es en la invención única, en la disposición artificiosissima, en la elocución con muchos colores oratorios suprema. Tantas y tan excelentes descriptiones de tiempos y lugares, comparaciones, metaphoras y alegorías, que solo el Ovidio basta en lugar de todos los poetas. Y ansi como la lengua es facultad, sin la qual está casi cerrada la puerta para las otras sciencias a qualquiera, aunque muy agudo y diligente sea, nuestro poeta es tal que sin él no se pueden entender ni gozar los otros poetas excelentes y con la noticia desta divina poesía, la tendrá de todos el curioso lector. ${ }^{15}$

Para Sánchez de Viana, como para muchos mitógrafos del Renacimiento, Ovidio es pues necesario ante todo para entender a los poetas ; las Metamorfosis nos enseñan el alfabeto, los rudimentos de la lengua sin la cual la poesía es ininteligible ${ }^{16}$.

15 Pedro Sánchez de Viana, Las Transformaciones de Ovidio traduzidas del verso Latino, en tercetos y octavas rimas. Por el licenciado Viana. Con el comento y Explicacion de las Fabulas : reduziendolas a Philosophia Natural y Moral y Astrologia e Historia. Valladolid, Diego Fernández de Cordova, 1589 ("A los lectores").

16 En los últimos años, el helenista Georges Calame, reaccionando frente a ciertos excesos del método estructural, invita a aplicar a la mitología griego un método "enunciativo y pragmático" que tenga en cuenta las condiciones de enunciación del mito. Como el mito tal como nos ha llegado es inseparable de la poesía, esta renovada hermenéutica mitológica es, al mismo tiempo, una poética. Ver Georges 
El famoso Libro de la erudición poética de Luis Carrillo (publicado póstumamente en 1611) no trata explícitamente del posible vínculo entre las fábulas y la “dificultad poética" cuya necesidad defiende. Para Carrillo, como antes para Herrera, toda la poesía consiste en la "elocución", único componente del discurso que distingue al poeta del orador y del historiador. No obstante puntualiza que "historia con fábulas es el argumento del poeta ; historia, la del historiador"17 Aunque Carrillo conocía probablemente la definición aristotélica de la "fábula" que la hace equivaler a cualquier clase de ficción, las fábulas a las que parece referirse son por antonomasia las narraciones que hoy llamamos mitológicas. De la enredada argumentación de su discurso se desprende la idea de que la elocución artificiosa distintiva del poeta consiste en un uso más libre e inventivo del léxico, de la sintaxis y de las figuras. Éste a su vez se basa en la erudición poética, es decir, en una dicción donde las palabras mismas encierran un meollo doctrinal, están marcadas con el cuño de la ciencia. Una ciencia enciclopédica, la de las bellas letras, que se adquiere frecuentando a los clásicos. Ciertamente, la erudición poética abraza al universo desde la cosmología a la jurisprudencia pero su epicentro son las fábulas, el mundo habitado por dioses y héroes, sátiros, faunos y ninfas, de cuya misteriosa realidad e inagotable significado los poetas son guardianes y depositarios.

El problema de la lengua poética, que preocupa a adversarios y defensores del gongorismo, lo resuelve con elegancia Vázquez Siruela en un Discurso sobre el estilo de Don Luis de Góngora y carácter legítimo de la poética (datado hacia 1645). Para Vázquez Siruela, la suma alabanza que puede hacerse a Góngora es reconocer precisamente lo que le reprochan sus detractores, que Góngora escribió no el castellano popular sino una lengua forastera. No hay mayor grandeza en un poeta que "viva una lengua, concebir otra ; formar su dialecto, dotalla de riquísimo patrimonio y dexalla con términos y Jurisdición distinta"18. Ahora bien, este problema de la lengua tal vez sea inseparable del que plantea el uso de la fábula antigua como lengua dentro de la lengua, como idiolecto poético. Para la poesía renacentista y barroca, heredera en esto como en tantas cosas de la poesía latina, los álamos son Helíades, el rocío lágrimas de Aurora, y la misma aurora la esposa de Titón. La curiosa inflexión que recibe el castellano en manos de Góngora, transformándose en algo ni del todo ajeno ni del todo propio,

Calame, Poétique des mythes dans la Grèce antique, Paris, Hachette, 2000.

17 Luis Carrillo, Libro de la erudición poética en Obras (ed. Rosa Navarro Durán), Madrid, Castalia, pp. 321-395, cita pp 328-9.

18 Publicado en Miguel Artigas, Don Luis de Góngora : biografía y estudio crítico, Apéndice 5. Madrid, 1925, p. 391 y ss. ; y reeditado por Saiko Yoshida, "Martín Vázquez Siruela. Discurso sobre el estilo de don Luis de Góngora". Presentación, edición y notas", en Autour des Solitudes, ed. Par F. Cerdan et M. Vitse, Toulouse, Presses Universitaires du Mirail; 1995, pp. 89-106. 
en una fascinante y familiar extrañeza, la recibe también en sus manos el idiolecto mitológico, lengua erudita y sagrada que distingue al poeta del vulgo.

Desde los albores del Renacimiento, esa lengua específica, señal de la elección del poeta, debe dar acceso a un mundo para iniciados, a "cosas escondidas", como escribe Carrillo, a la "Idea de la escondida, altísima poesía” ${ }^{19}$, como escribe Jáuregui, mundo que viene a reemplazar el de la experiencia común, y que a la vez lo revela. Pero hay que confesar que esta virtud reveladora no resulta por lo general demasiado convincente. Lo habitual es que el uso de la mitología se atenga al que aparece cristalizado en la tradición petrarquista. La fábula engendra un número limitado de situaciones prototípicas, que son el equivalente imaginario de un momento del drama subjetivo, filtrado en teoría por una perspectiva universal de alcance filosófico o, lo que viene a ser lo mismo en términos prácticos, vertido en los tópicos de la poesía lírica. La fábula, en otros términos, remite a un lugar común del discurso amoroso y alguna vez político o religioso: Venus llorando a Adonis es una figura de la pérdida desconsolada; Acteón, del deseo mortífero; Dafne, del honesto desdén... De modo análogo, en la poesía llamada heroica, cualquier militar de noble alcurnia está "representando en tierra al fiero Marte", como escribe Garcilaso, y los Gigantes que quisieron escalar el cielo pueden ser prototipo de los enemigos infieles o herejes de la potencia hispánica.

Algo distinto sucede en los poemas que se presentan como fábulas, como pequeñas epopeyas, al modo del epyllion antiguo, y en los cuales el mito, de ser puro adyuvante de la dicción poética, elemento de un idioma, se convierte en la materia misma del mensaje. A través de estos poemas, en cierto modo meta-poéticos, como lo es Ovidio según Sánchez de Viana, se opera una asimilación de las principales fuentes de la materia mitológica y ante todo de Ovidio. De ahí su naturaleza de ejercicios, su carácter algo escolar. De las fábulas renacentistas estudiadas por Cossío muy pocas se leen hoy, salvo en el marco de la erudición de especialistas. Muchos estudiantes y aficionados a la poesía guardan memoria de algún soneto de Hernando de Acuña, de alguna copla satírica de Diego Hurtado de Mendoza, o de la deslumbrante Epístola a Arias Montano de Francisco de Aldana. ¿Quién ha leído, o recuerda con precisión, la Fábula de Narciso de Acuña, la Fábula de Venus y Adonis de Hurtado de Mendoza ${ }^{20}$ o la

19 Juan de Jáuregui : “Silva a un amigo docto y malcontento de sus obras” en Poesía (ed. J. Matas), Madrid, Cátedra, 1993, pp. 263-67. José Manuel Rico García, marcando lo muy significativo de este verso en la poética de Jáuregui, toma de él el título de su excelente estudio, La "perfecta idea de la altísima poesía". Las ideas estéticas de Juan de Jáuregui, Sevilla, Diputación, 2002.

20 Véase un esclarecedor análisis de las prácticas de la imitación en esta fábula en el artículo de J.Roses, « La Fábula de Adonis, Hipomenes y Atalanta de Diego Hurtado de Mendoza : grados de la imitación renacentista », Congreso Internacional sobre Humanismo y Renacimiento (1996, León), coord. J. Matas Caballero, Universidad de León, 1998, pp. 123-148. Este poema de hermosa factura anterior a 1549 es interesante por su precocidad. El poeta humanista practica, como muestra con pericia Joaquín Roses, la llamada imitación múltiple. Entendamos que aquí y allá aparecen en su fábula teselas perfectamente re- 
Fábula de Faetonte de Aldana? Los temas elegidos en estas fábulas del siglo XVI son casi siempre las diez o quince historias favoritas de la lírica, invariablemente seleccionadas en el copioso torrente de historias que contienen Las Metamorfosis. Resulta difícil a los poetas que emprenden la composición de estas fábulas distanciarse del texto cuya pauta siguen, despegarse de la letra del poeta clásico. Por ello, el autor de "fábulas" suele limitar su tarea a una traducción inconfesada de un texto que es a veces el de Ovidio, a veces el de alguna de sus traducciones o paráfrasis italianas.

Unalectura del Polifemo gongorino, seguida o precedida porla delcorrespondiente pasaje ovidiano, basta para convencerse de que en ningún modo se da en Góngora el mismo grado de dependencia con respecto al modelo. Aunque Dámaso Alonso en su artículo sobre "la supuesta imitación" de Carrillo por Góngora, y Antonio Vilanova en su libro monumental ${ }^{21}$ no lo hubieran demostrado con creces, estaría claro que la relación entre el texto y el modelo es indirecta, que la historia de Ovidio ha sido filtrada por una compleja elaboración que exigía la ingestión y transformación de un abundante acervo de textos, muchos de ellos relacionados con el tema polifémico, antiguos y modernos, y otros sin relación con él. Pero lo mismo sucede en todas las poesías de alguna importancia posteriores al Polifemo y de él inspiradas, las fábulas de Lope de Vega, Jáuregui, Villamediana ${ }^{22}$, Soto de Rojas ${ }^{23}$, Faria y Sousa, Bermúdez y

conocibles que derivan de diversos poetas, Horacio, Garcilaso, Claudiano, Virgilio, Lucrecio o incluso el griego Bión de Esmirna y su « Canto fúnebre por Adonis ». Sin embargo se trata precisamente de teselas, incrustaciones en un tejido que es ovidiano no sólo en el orden del relato, en la dispositio, sino también en los detalles de la elocución. Puede hablarse todavía de traducción, aunque muy libre y ambiciosa, como si el traductor compitiese con el autor original. Como escribe el citado estudioso : « La lealtad de Mendoza a su modelo, lejos de limitarse a traslaciones de contenido más o menos afortunadas, se extiende al ornato poético en el nivel expresivo. » (p.130). Imitando a varios, se permanece siempre bajo la tutela de uno solo. Los demás autores imitados se integran pero sin que se borren los límites entre lo que les pertenece y lo que pertenece al autor seguido en el cuerpo del texto. Se integran pues a título de voluta, arabesco o amplificación ornamental. Como veremos, la imitación múltiple cobra en la fábula barroca un sentido más radical. El poeta se desprende casi por completo del texto de su fuente, reinventa la narración y si pese a todo recoge o adapta hallazgos expresivos de Ovidio, lo hace de manera no sistemática y dándoles una forma muy alterada, disfrazada o híbrida.

21 A. Vilanova : Las fuentes y los temas del "Polifemo" de Góngora. Barcelona, PPU, 1990, 2 vols. (1a ed. 1957). Para el descubrimiento de fuentes (desconocidas hasta ahora) en el epilio gongorino, remito a la nueva edición cuidada por Jesús Ponce Cárdenas: Fábula de Polifemo y Galatea, Madrid, Cátedra, 2010.

22 Fábula de Faetón (1617), Fábula de Apolo y Dafne, Fábula de Europa, Fábula de la Fénix. La primera fue traducida en hexámetros latinos por Vicente Mariner. Las cuatro fábulas, así como la interesante traducción latina, pueden leerse por separado en la edición de L. Gutiérrez Arranz, Conde de Villamediana, Las fábulas mitológicas, Kassel, Reichenberger, 1999.

23 Los Fragmentos de Adonis, publicados en 1652 junto con el famoso Paraíso cerrado para muchos, fueron escritos hacia 1619 (Véase P. Soto de Rojas, Paraíso cerrado para muchos, jardines abiertos para pocos. Fragmentos del Adonis, ed. de A. Egido, Madrid, Cátedra, 1980). Algo posterior es Los rayos de Faetón del mismo poeta, fábula publicada en 1637, pero que debió escribirse antes de 1627. Véase la edición de Los rayos de Faetón de G. Cabello Porras, Universidad de Málaga, 1996. 
Alfaro $^{24}$, Pérez de Montalbán ${ }^{25}$, escritas todas entre 1617 y 1624, o incluso en un texto más breve y menos ambicioso como la Fábula de Pan y Siringa incluida por Tirso en Los cigarrales de Toledo ${ }^{26}$.

\subsection{De la amplificación novelesca a la recreación del mito. Faetón en Aldana y Villamediana}

Para hacerse una idea aproximada de la distancia que separa las más típicas fábulas renacentistas de la fábula barroca, posterior a Góngora, tal vez baste comparar dos de los mejores poemas estudiados en la monografía de Gallego Morell sobre El mito de Faetón en la literatura española ${ }^{27}$, el Faetón de Aldana ${ }^{28}$, escrito hacia 1560 y el de Villamediana ${ }^{29}$, al que dedica Góngora un soneto y una memorable décima, ambos fechados en 1617. No es que el último sea necesariamente mejor. La Fábula de Faetonte de Aldana puede resultar bastante más agradable que el bronco y escarpado poema de Juan de Tassis. Lo importante es que en este último la huella de Góngora se siente como un cataclismo tan formidable como el incendio cósmico que desencadena la hazaña de Faetonte. Aldana escribe su fábula en endecasílabos sueltos, traduce a Luigi Alamanni en una gran parte de su poema, pero volviendo a Ovidio en numerosas ocasiones ${ }^{30}$. Su propósito manifiesto es aclimatar al castellano el texto latino. También se propone acoger líricamente el tema, esbozar la identificación entre un "yo" sujeto de la lírica y el héroe mitológico:

Triste pienso cantar de ti, Faetonte, y hago un duro ejemplo de mí mismo pues el tuyo y el mío fue un mismo ejemplo, una misma caída, un mismo daño. ${ }^{31}$

24 El sevillano Juan Bermúdez y Alfaro publica en 1618, en Lisboa, un poema en tres cantos en octavas reales titulado El Narciso. Flor traducida del Cefiso al Betis. He consultado la edición de Fernando Gutiérrez, Barcelona, Ediciones bibliófilas, 1953. La influencia de Góngora es evidente en este poema, como lo indica F. Gutiérrez en su prólogo, p.12.

25 El Orfeo en lengua castellana fue publicado en Madrid, por la viuda de Alonso Martín, en 1624. Véase la edición de P. Cabañas, Madrid, CSIC, 1948.

26 Esta fábula, incluida en Los cigarrales de Toledo (1621), es atribuida a Fray Plácido de Aguilar. Puede leerse en Tirso de Molina : Poesías líricas, ed. de E. Jareño, Madrid, Castalia,1980, p. 207-219.

27 Madrid, CSIC, 1961.

28 Francisco de Aldana, Fábula de Faetonte en Poesías Castellanas Completas, ed. de J. Lara Garrido, Madrid, Cátedra, 1985, p. 148-187.

29 A la edición más reciente de J. F. Ruiz Casanova, muy deficientemente anotada y plagada de feas erratas, es preferible la edición de J. M. Rozas en Villamediana, Obras. Madrid, Castalia, 1969, p. 203266, a pesar de su parca anotación. Citaré el poema por la mencionada edición de L. Gutiérrez Arranz [1999].

30 Las excelentes notas al poema en la edición citada de José Lara Garrido permiten ver con precisión este proceso de «imitación compuesta ».

31 Versos 50-53. 
La prolija amplificación de Aldana se explaya sobre todo en los pasajes más humanos, más dramáticos y emotivos. En Ovidio, la narración de este mito comienza por evocar brevemente la rivalidad de dos jóvenes de ascendencia divina, Épafo, hijo de Júpiter y Faetón, hijo de Apolo, rivalidad que estimula el afán de gloria del héroe. En la fábula renacentista, el incidente se transforma en una larga escena precursora de las que abundarán en las futuras comedia y novela. Jóvenes nobles, arrogantes y fogosos, riñen acerca de linajes, con una vehemencia agresiva que es muy propia de la España de siglo XVI. Del mismo modo, Aldana amplifica patéticamente el llanto de la "viuda madre" de Faetonte cuya lamentación ante el cadáver del hijo tiene el acento noble y desgarrador del llanto de la Virgen ante Cristo muerto. La enumeración de ríos consumidos por el ardor del sol al acercarse el carro de Faetón, se transforma en un inventario agotador : a los ríos citados por Ovidio, el Tanais, el Peneo, el Erimanto, el Janto, el Meandro y el Eurotas, el Nilo, el Tajo, el Ebro, el Tíber, se añaden numerosos ríos europeos menos puramente poéticos. El efecto de conjunto consiste en acercar la fábula al presente, en dotarla de una verosimilitud de tipo teatral o novelesco, pero sin añadir nada a su propia sustancia de mito.

Completamente distinta es la empresa de Villamediana. Desde luego, el orden de su narración procede estrictamente de Ovidio y no de una refundición completa del relato como la que se observa en el Polifemo. Pero la amplificación difumina todo parecido con el modelo. Villamediana no parece tener interés alguno en acercar la fábula a la común realidad humana, en dotarla de verosimilitud dramática y ética. Los afectos que brotan del relato ovidiano, la inquietud del padre y la trampa trágica en que se ve atrapado por la palabra dada al hijo, la conmovedora arrogancia juvenil del héroe y luego su pánico infantil, la desolación de la madre y de las hermanas, están tratados con sobriedad o más bien sequedad, incluso en los pasajes dialogados, de por sí más propensos al drama y la moralización. No se trata pues, como en las fábulas del XVI, de insistir en el análisis de caracteres y pasiones apuntados con elegancia por el poeta antiguo. Lo que predomina en el poema de Villamediana es la contraposición entre una "isotopía" del esplendor y una "isotopía" del desorden, el contraste explosivo de la luz y del caos, que aflora por todas partes y que estalla como un fuego de artificio en los versos más característicos : “del que estrellas pisando en carro de oro / desenfrenó la luz con mano osada" 32 ... o bien "cuyo vuelo inmortal pudo sin plumas / espumar rayos, radiar espumas" ${ }^{\prime 3}$.

Cada octava suele estar organizada en torno a un concepto, del mismo modo que en Góngora aunque con menos destreza. El repaso de estos conceptos permitiría

32 Versos 19-20

33 Versos 959-60. 
reconocer buena parte de las agudezas descritas por Gracián. El "encarecimiento", la paradoja, la alusión, la sentencia, la correspondencia, la ponderación se prodigan a lo largo del poema. El propósito global, la "agudeza compuesta" que le da unidad podría ilustrarse con un sintagma como "desenfrenó la luz", que encierra una serie de equívocos y de disonancias. La raíz léxica "desenfreno", normalmente usada en sentido abstracto y moral, exige aquí que se tenga en cuenta su significado concreto y material, puesto que lo que hace Faetón es quitar el freno al carro del sol. Al ser el carro sustituido por la luz, de nuevo el freno se vuelve inmaterial o al menos intangible: desenfrenar la luz, añadir dinamismo a la misma energía, es como quemar el fuego, algo contradictorio e impensable. Esta expresión de lo impensable se aplica con propiedad sin embargo -mediante el desplazamiento metonímico del carro del sol a la luz (del continente al contenido)- al acto trasgresor del héroe. En el sintagma "desenfrenó la luz" se condensan el horror y la admiración que el poeta pretende inspirar por la hazaña de Faetón. La conversión del horror en espectáculo admirable, la gloria como antesala del infierno, la belleza como esplendor de un objeto ya casi destruido, son posibles expresiones de esta idea central que subyace también a otros muchos conceptos del poema. Aunque en muy distinta manera, algo así se da también en el Polifemo, poema en el que el tratamiento exquisito de la conjunción entre dos cuerpos perfectos podría evocar una escena galante de boudoir rococó, si la sombra funesta del cíclope no pesara sobre ella.

Ciertamente, ya en el relato ovidiano de la historia de Faetón, la sustancia poética del relato depende en gran parte de la catástrofe como gran espectáculo, como teatro de maravillosa crueldad. Pero este aspecto del texto clásico, tan en consonancia con la sensibilidad barroca, se intensifica de modo paroxístico en el poema del conde. En Ovidio, la cabellera rutilante de Faetón se incendia cobrando el aspecto de una estrella fugaz. En la fábula de Villamediana, la luz del cabello incendiado es una lámpara para la belleza del rostro :

\footnotetext{
Admiraron los orbes el cabello que ni tierra exhaló, ni formó viento, lastimoso prodigio, pero bello, bello rostro alumbró con su cabello. ${ }^{34}$
}

La hazaña del héroe es reproducida a su manera por el poeta en un arte heroico, que pretende, mediante las asperezas del cultismo y el hipérbaton, producir un cosmos verbal fulgurante y la vez cataclísmico. La descripción del palacio del Sol y de su decoración pictórica y escultórica, amplificada a partir del relato de las Metamorfosis, permite aludir enigmáticamente a multitud de personajes y episodios mitológicos, enmarcados en una, dos o tres octavas. El mundo de la fábula se presenta como un 
universo íntegro y radiante, un programa iconográfico para una morada regia, como en la serie de los cuadros de Rubens para la Torre de la Parada. En la descripción de la carrera, este mismo mundo vuelve a aparecer en estado convulso, presa de un fuego que lo destroza. El poema se detiene largamente en la llegada del fuego a los infiernos, el desorden luminoso de origen celeste que invade hasta la morada del fuego tenebroso y del dolor subterráneo. El paroxismo de este infierno redoblado, de este Apocalipsis infernal, suscita evidentemente el máximo interés de Villamediana ${ }^{35}$ :

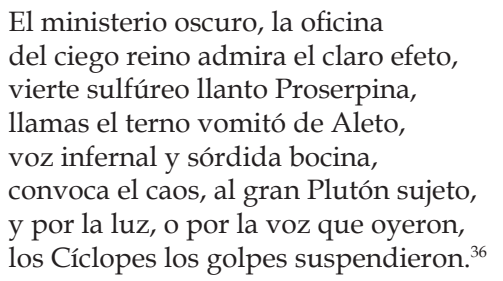

En conjunto, estamos ante una interpretación y recreación del mito más que ante la reescritura de un texto. Este trabajo mitográfico exige una apropiación del conjunto de las "fábulas" clásicas, entendidas como un complejo sistema, y no simplemente un esfuerzo de familiarizarse con él, o de acercarlo a nuestro mundo.

\subsection{El eclipse de la fábula renacentista}

La relativa escasez de narraciones ovidianas en la poesía española hacia 1600 se explica por la erosión de las motivaciones que animaban a los autores de fábulas renacentistas, afán de ejercicio estilístico y deseo de familiarizarse con el material mitológico. La aparición de varias traducciones en verso de las Metamorfosis durante la década de $1580^{37}$, probablemente hiciera juzgar vanas esas empresas, retirándoles lo

35 Vv. 1377-1480. Las fábulas barrocas frecuentan los episodios infernales, propicios a la hipérbole, la paradoja, la imitación compuesta y los grandes efectos paisajísticos y tenebristas. No faltan en La Circe de Lope, como tampoco, como es lógico en los dos Orfeos de 1624, el de Jáuregui y el atribuido a Pérez de Montalbán. En su descripción « las cavernas del tormento eterno », el autor del Orfeo en lengua castellana aligera los tintes trágicos, oscuros y horrendos, porque, según escribe, aspira a «poner mayor estudio en la hermosura ». De modo que el hecho de representar los infiernos, es decir el reino de las "tinieblas", es ocasión de tomar partido contra la oscuridad, y contra los « fieros escorzos » a los que tan aficionado era Jáuregui según sus detractores. Como escribe Jesús Ponce : « La fábula se convierte en un campo más de la batalla literaria que oponía cultismo y casticismo, dividiendo la escena literaria en dos banderías encabezadas, respectivamente, por Góngora y Lope. Precisamente, en la defensa de la llaneza que lleva a cabo el narrador [del Orfeo en lengua castellana] quizá pueda residir una de las claves de la omisión del catálogo de los condenados, ya que al desecharse las amplificationes de carácter culto se llega a tejer un relato más « sencillo », menos artificioso que el del « Orfeo trilingüe de Jáuregui. »( J. Ponce, « Impia dilatis respirant Tartara poenis : notas sobre el catálogo de reos infernales en la literatura latina y su proyección en la poesía española ", en J. Matas., J.M. Trabado, J.J. Alonso, La maravilla escrita. Torquemada y el siglo de oro, León, Secretariado de publicaciones, 2005, pp. 605-626.

36 Vv. 1385-1392.

37 Del Metamorfoseos de Ovidio en otava rima, traduzido por Felipe Mey. En Tarragona por Felipe Mey. 
que podían conservar todavía de arduo y de inédito. Los comentarios que acompañan a las traducciones de Felipe Mey y Sánchez de Viana, la edición y la amplia difusión, en las postrimerías del XVI, del libro de un mitógrafo como Pérez de Moya ${ }^{38}$, preludiaban una visión diferente del mito, más afín al alegorismo medieval aunque difiriera profundamente de él. Según esta nueva visión, el mundo de la fábula constituía un sistema simbólico flexible capaz de irradiar significaciones nuevas y no sólo de ofrecer bonitas historias e ilustrar lugares comunes.

Los ecos de Ovidio parecen refugiarse entonces en textos que se apartan resueltamente de la mera paráfrasis. Una de las posibilidades de renovación de esta materia consiste en inventar nuevas historias a la manera de Ovidio, con frecuencia cruzando con virtuosismo lúdico y alardes de recóndita erudición varios modelos o varios patrones genéricos. Así proceden típicamente los poetas "manieristas" al enfrentarse con el material de los relatos clásicos, como se observa en algunas composiciones de Barahona de Soto, tal vez el más cercano precursor entre los poetas del XVI a lo que será la poética de Góngora ${ }^{39}$. Valga como ejemplo su elegía III, “Furioso río, cuya limpia arena", refinada variación jocoseria sobre una elegía ovidiana (Amores III, 6). Este poema de Barahona incluye una "fábula" inventada, la de "Dauro y Lateja", que resulta de la recreación de la leyenda forjada por Ovidio acerca de la ninfa Ilia violada por Marte y casada con un río. Así Barahona, en el marco de una bella elegía amorosa con matices paródicos, combina el mito con una alegoría topográfica, anclando la fábula en el paisaje local granadino ${ }^{40}$. Algo similar hará Espinosa en la Fábula del Genil $^{41}$ o Faria y Sousa en Galia y Flaminia. Lope en su Arcadia incluye a un gigante

1586. Las transformaciones de Ovidio. Traducidas del verso Latino, en tercetos y octavas rimas. Por el Licenciado Viana. En lengua vulgar castellana. con el comento y explicación de las Fábulas : reduziendolas a Philosophia natural y moral y Astrologia e Historia [...] Valladolid, Diego Fernández de Cordova,1589.

Metamorphoseos del excelente poeta Ovidio Nasón. Traduzidos en verso suelto y octava rima con sus allegorías al fin de cada libro. Por el Doctor Antonio Pérez Sigler natural de Salamanca. Nuevamente agora enmendados y añadido por el mismo autor un Diccionario Poético copiosissimo [...] Burgos, Iuan Baptista Varesio, 1609 (La primera impresión de esta traducción es de 1580).

38 Juan Pérez de Moya, Philosophia secreta. Zaragoza, M. F. Sánchez, 1599. Edición moderna de E. Gómez de Baquero, Madrid, Los Clásicos olvidados, 1928 , 2 vols y más reciente de C. Clavería, Madrid, Cátedra, 1995.

39 Como muestran los trabajos de J. Lara Garrido recogidos en su La poesía de Luis Barahona de Soto. Lírica y épica del manierismo, Diputación Provincial de Málaga, 1994.

40 Véanse al respecto dos estudios magistrales « La elegía III de Barahona de Soto. El ámbito fluvial como encrucijada genérica », de G. Cabello Porras y J. Campos Daroca, y « Naturaleza, topografía y mito en la poesía de Barahona de Soto », de J. Fernández Dougnac, ambos en J. Lara Garrido (ed.), De saber poético y verso peregrino. La invención manierista en Luis Barahona de Soto. Analecta Malacitana, Universidad de Málaga, 2002, pp. 202-229 y pp. 227-256.

41 Muy bien estudiada recientemente por Belén Molina, Tras la estela del mito. Texto y recepción en la «Fábula del Genil » de Pedro Espinosa, Málaga, Universidad, 2005. El texto, cuidadosamente anotado por la misma investigadora, puede leerse en Pedro Espinosa, Flores de poetas ilustres, ed. de B. Molina Huete, Sevilla, Fundación José Manuel Lara, 2005, pp. 318-340. 
polifémico llamado Alastor, enamorado de una ninfa, como lo había hecho Ariosto en el Orlando ${ }^{42}$. Pero estos ensayos, que en las postrimerías del XVI constituyen la forma más novedosa de habérselas con el material mitológico, incluso cuando dan lugar a resultados tan brillantes como la influyente fábula de Pedro Espinosa, se quedan en variaciones decorativas que renuncian a competir con la grandeza épica y trágica de los grandes relatos clásicos.

Otra modalidad, totalmente opuesta, de renovación de la materia ovidiana, se manifiesta en la reducción epigramática de las fábulas, presente en la poesía española desde el soneto a Dafne de Garcilaso o la descripción de los tapices tejidos por las ninfas en la égloga tercera y que será practicada sistemáticamente en muchos sonetos de Jáuregui, de Quevedo, de Lope de Vega, y en una larga serie de sonetos de Juan de Arguijo, precedentes de muchos sonetos barrocos. Los sonetos de Arguijo, escritos hacia 1600, A los gigantes que combatieron el cielo, A Hércules, A Baco, A Faetón, A Icaro, a Sísifo, A Tántalo, A una estatua de Niobe, A Dafne, etc. son el equivalente castellano de ciertos epigramas neolatinos, los de Julio César Escalígero por ejemplo ${ }^{43}$. Su efecto estriba en la condensación del relato, o más bien su miniaturización en una viñeta presentada en los cuartetos mientras el comentario ingenioso queda reservado a los tercetos. En los casos más triviales, el comentario se funda en la identificación del locutor en su calidad de amante con el héroe mitológico. En los más curiosos, se forja una interpretación del mito mediante un concepto agudo o sentencioso, como en la "observación sublime" ${ }^{44}$, en términos de Gracián, que concluye un soneto a Ganimedes :

42 Con el personaje del gigante Orco, construido a partir de ingredientes polifémicos tomados de Homero, Virgilio y Ovidio. Del tratamiento por Ariosto de este gigante caníbal se aprovechó también Góngora en el Polifemo, como indica José María Micó en un artículo dedicado a " Ariosto en el Polifemo », Góngora Hoy VII. El Polifemo, ed.cit., pp. 139-156.

43 Julii Caesaris Scaligeris Novorum epigrammatum liber unicus [...] Parisiis apud M. Vascosanum, 1533. En su reciente y muy docta edición de Arguijo, Gaspar Garrote Bernal y Vicente Cristóbal ponen de relieve el carácter epigramático de los sonetos, no sólo válido para los que derivan de epigramas (de Ausonio, de Fausto Sabeo, de anónimos de la Antología Palatina) sino también para los que proceden de fuentes no epigramáticas como el mismo Ovidio. Los humanistas, siguiendo un camino trazado por el epigrama antiguo, exponen a veces en forma condensada y glosada un suceso legendario o histórico. Así en la serie Heroes de los epigramas de Escalígero o en los cinco libros de epigramas de Fausto Sabeo. M. Gabrielle Symeoni encierra cada episodio de las Metamorfosis en el espacio de una octava, asociada a un grabado, en su La vita et Metamorfoseo d'Ovidio figurato et abbreviato in forma d'Epigrammi (1584). Véase "Introducción" de Juan de Arguijo, Poesía, ed. de G. Garrote y V. Cristóbal Sevilla, Fundación José Manuel Lara, 2004, p. XCV y ss.

44 «Hay unas verdades realzadas, así por lo substancial como por lo extraordinario, cuya observación es acto relevante de la capacidad [...] Consiste su perfección más en la sublimidad del conocimiento que en la delicadeza del artificio : dan mucha satisfacción por su enseñanza e iluminan realzadamente el ánimo. » (Baltasar Gracián, Agudeza y arte de ingenio, Discurso XLIII, « De las observaciones sublimes y las máximas prudenciales » ed. de C. Peralta, J.M. Ayala y J. M. Andreu, Prensas Universitarias de Zaragoza, 2004, vol. II , p.464). Creemos que la noción de « observación sublime » se aplica bien a la coda del soneto de Arguijo. El terceto final nos lleva observar que sólo el amor divino puede atraer hacia lo alto, y que responder a su llamamiento exige que desechemos el amor por la patria terrestre (« Olvida tu amada Troya »). La observación es en sí baladí pero cobra toda su fuerza del contexto y los términos 
No temas, o bellísimo troyano viendo que, arrebatado en nuevo vuelo con corvas uñas te levanta al cielo la feroz ave por el aire vano. ¿ Nunca has oído el nombre soberano del alto Olimpo, la piedad y el celo de Júpiter, que da la pluvia al cielo y arma con rayos la tonante mano ? ¿A cuyas sacras aras humillado gruesos toros ofrece el Teucro en Ida implorando remedio a sus querellas? El mismo soy. No al águila eres dado en despojo ; mi amor te trae. Olvida tu amada Troya y sube a las estrellas ${ }^{45}$.

Hay que esperar los tres últimos versos para saber que es Júpiter quien habla, y para percibir el vuelco del significado que transforma la violencia en elección y el rapto por un animal de presa en un arrobo extático, en un vuelo hacia la divinidad ${ }^{46}$. Siguiendo la pauta de sonetos como el citado, las reflexiones ingeniosas de acento sublime o jocoso a las que se presta una materia narrativa desgastada, hubieran tal vez prolongado los ecos de la fábula en el marco estrecho de formas poéticas breves, epigramáticas, sin el poderoso efecto que ejerce, desde el primer momento de su difusión en 1613, la Fábula de Polifemo y Galatea.

inesperados en que se presenta, o dicho de otro modo de la « circunstancia especial » de la que arranca. Ahora bien la " circunstancia especial » o el « decir a la ocasión », son, digámoslo así, la signatura del ingenio. Cuando la idea sublime brota de la circunstancia especial se vuelve conceptuosa y, lo que tal vez sea lo mismo, poética.

45 Véase el texto (y el comentario) de este poema en Stanko B. Vranich, Obra completa de Don Juan de Arguijo, Valencia, Albatros Hispanofila, 1985, pp.158-162.

46 Arguijo presenta su soneto como "traducción" de un poema latino de Fracastoro. De hecho traduce efectivamente un fragmento de este poema, que reproduce Stanko B. Vranich en su edición comentada (S. B. Vranich, Obra completa de Don Juan de Arguijo, Valencia, Albatros Hispanofila, 1985, pp.158-162). Se incluye este poema en el tratado De anima en el que el rapto de Ganimedes simboliza la ascensión del alma al cielo. Los cuartetos del soneto castellano son en efecto una fiel y acertada traducción: "Ne timeas Troiane puer, quod in ardua tantum / Tolleris a terra : quod rostro, atque unguibus uncis / Te complexa ferox volucris per inania portat..." Sin embargo, el soneto de Arguijo, comparado con su modelo, se distingue por la concisión, la brusquedad y la energía del final. "Mi amor te trae" (expresión sin equivalente exacto en el modelo) sorprende y dice mucho pocas palabras, dejando tal vez abierta cierta ambigüedad entre amor humano y amor divino que el poema de Fracastoro eliminaba de raíz con un muy explícito desarrollo de obediencia neoplatónica.

Estas interpretaciones del mito se reflejan todavía en un poema de Goethe sobre el que compusieron lieder Schubert y Wolf. Goethe convierte también al rapto de Ganímedes en alegoría del rapto místico, y su vuelo en éxtasis que lo transporta hacia el Padre divino. Sobre el tema hay una nota interesante de Luis Antonio de Villena, "Los raptos de Ganímedes (Notas sobre el tema paídico, en pinturas y sonetos del Barroco)", Nueva Estafeta, V, abril 1979, pp. 50-55 ; véase sobre todo la monografía muy completa de M. Saslow, Ganimedes en el Renacimiento : la homosexualidad en el arte y en la sociedad, Madrid, Nerea, 1989. 


\section{La fábula a Raíz del "Polifemo"}

\subsection{La importancia estratégica del género}

El impacto inmediato del Polifemo, al que enseguida se superpone el de las Soledades, se verifica en el mimetismo estilístico observable en casi todos los poetas de alguna importancia ${ }^{47}$. El fenómeno no puede escapar ni al examen más superficial en un ferviente admirador de Góngora como Villamediana. Basta una lectura cursiva de la Fábula de Faetón para reunir una abundante cosecha de versos que llevan la marca inconfundible del admirado modelo o que simplemente, han sido tomados de él: "estrellas dora tantas como espigas" (400), "discurre undoso, volador no alado" (401), "émulo nácar del mejor diamante (439), "rémoras son tenaces a su planta" (525), "robó de su candor los alhelíes " (529), "coros pintados de lascivas aves" (676) "los archivos diáfanos del viento" (1208) "montes de agua y piélagos de montes"(1654). También proceden inequívocamente de Góngora otros rasgos notables del poema de Villamediana, como el uso sistemático y lúdico de la perífrasis para denominar al personaje mitológico ${ }^{48}$. Así, sobre la pauta de las perífrasis de Las Soledades como "el mentido robador de Europa” (Júpiter), “el garzón de Ida” (Ganimedes), "la hija de la espuma” (Venus), "el monarca de esas grutas hondas" (Neptuno), encontramos en el Faetón de Villamediana, "el denuedo argólico volante" para designar a Perseo, "el que nació gigante", para Hércules, "el gran pastor que vio desnuda en Ida / de tres deidades compartida gloria", para referirse a Paris. Lo que en Villamediana se exhibe como vindicación de los poderes mágicos del modelo se vuelve en los adversarios de Góngora, como Lope ${ }^{49}$, una tentación vergonzante y encubierta, pero nadie escapa a la compulsión de integrar fragmentos del nuevo lenguaje .

47 Mimetismo que en lo que respecta a la fábula recuerda en estos términos Juan Matas Caballero en la introducción a su reciente colección de artículos sobre la poesía áurea : « ...es cierto que la Filomena [de Lope de Vega] se creó bajo la estela mítica creada por el Polifemo de Góngora, y que esta genial creación terminó convirtiéndose, ya en su tiempo, en el canon de la poesía mitológica [...] » (J. Matas Caballero, Espada del Olvido. Poesía del Siglo de Oro a la Sombra del Canon, Universidad de León, 2005, p. 12). Entre las anotaciones y comentarios que consagra Jesús Ponce Cárdenas a las octavas del epilio gongorino, se consignan numerosas variaciones sobre el modelo polifémico debidas a la pluma del conde de Villamediana, Pedro Soto de Rojas, fray Plácido de Aguilar, Juan de Moncayo y Gurrea, Jerónimo de Porras, Agustín de Salazar y Torres, Antonio Enríquez Gómez, Lorenzo de las Llamosas, Hernando Domínguez Camargo y muchos otros ingenios: Fábula de Polifemo y Galatea, Madrid, Cátedra, 2010, pp. 178-354.

48 Como indican Gaspar Garrote Bernal y Vicente Cristóbal, la perífrasis -y especialmente la acuñada para designar a un personaje mitológico- es una práctica general en la dicción llamada « cultista », es decir en la propia de los poetas humanistas y eruditos o que quieren pasar por tales. Abunda en el mismo Juan de Arguijo (Véase Poesía, ed. cit., pp. LXXXIX y ss.). Sin embargo, las perífrasis de Góngora suelen ser notables por su complicación y carácter figurado e ingenioso. Por ejemplo « el que ministrar podía la copa a Júpiter mejor que el garzón de Ida », perífrasis que designa al protagonista de las Soledades, encierra una "paridad conceptuosa » y una segunda perífrasis : " garzón de Ida » por Ganimedes. Es esa complicación enigmática lo que intenta reproducir Villamediana.

49 En La Circe de Lope (1624), Dámaso Alonso señalaba los siguientes versos que imitan los finales 
Pero el impacto de los poemas gongorinos, la modificación instantánea de las líneas de fuerza en el campo literario, se traduce de modo no menos inequívoco por el furor con que los poetas-con algunas excepciones interesantes, como la de Quevedo -, se lanzan a practicar el género fábula. Entre 1621 y 1624, Tirso incluye una fábula en Los Cigarrales, Lope de Vega publica fábulas de Filomena, de Andrómeda, de Circe, Juan de Jáuregui, un Orfeo, Pérez de Montalbán otro Orfeo que debe mucho o todo a Lope de $\mathrm{Vega}^{50}$. El impulso se prolonga más allá de estos años en que todavía hierve la polémica, pero es probable que el género pierda paulatinamente, después de 1624, su actualidad candente, su papel decisivo entre las maniobras de seducción y de prestigio practicadas por los poetas más ambiciosos.

Esta importancia estratégica la corroboran múltiples datos. La Fábula de Acis de Carrillo, cuya difusión es contemporánea de la del poema gongorino, se imprime junto con uno de los escasos ensayos teóricos que debemos a los poetas del Siglo de Oro, El libro de la erudición poética. Jáuregui publica su Orfeo en 1624, en el mismo año que su Discurso poético, crítica muy meditada del gongorismo que aspira a sentar las bases de una poética ${ }^{51}$. El Orfeo se presenta pues como ilustración de una doctrina exigente, y por ello mismo se presta al malentendido y a la mala fe y despierta una rechifla ensordecedora $^{52}$. La Filomena y La Circe de Lope, de 1621 y 1624, libros variopintos

bimembres de octava a que tan aficionado era Góngora : « .. es Venus de aquel mar, del sol estrella. »; « adonde coge flores deja arenas »; " desnuda el campo y los panales dora »; « desprecias el coral y pisas flores »; « la que lienzo vistió nácares viste »; en La Filomena : « ..tu quejas en desdén, yo en nieve amores »; «.. si en las arenas o en el aire pisa »; «..que Venus deja a Apolo y sigue a Marte» ; « ..guerra de burlas y temor de veras »; como ejemplos de hipérbaton, citaba en La Andrómeda : « Ella, mirando al joven semideo, / mayores de dolor extremos hace. », y en el primer verso de La Filomena : « Dulcísima de amor ave engañada " (Poesía española. Ensayo de métodos y límites estilísticos, Madrid, Gredos, 1987 (1a ed, 1950), pp. 445-446. Recientemente Juan Matas ha estudiado los ecos de Góngora en La Filomena, especialmente en el episodio, inventado por Lope, del pastor Silvio (avatar de Polifemo) enamorado de Filomena («Lope de Vega tras la estela de Góngora : unos versos de La Filomena », La Espada del Olvido..., ed. cit. pp.153-181).

50 J. Pérez de Montalbán, Orfeo en lengua castellana, ed. Melquíades Prieto, prólogo de F. Pedraza, Aranjuez, Ara Iovis, 1991 (ed. facsímil). Felipe Pedraza da la razón a los que atribuyen este Orfeo a Lope -basándose en el testimonio de Nicolás Antonio y en observaciones estilísticas y coincidencias varias-, y entre otros a Miguel Artigas y Pablo Cabañas.

51 Como escribe Melchora Romanos : «.. el Orfeo sólo puede ser analizado a la luz de las ideas que Jáuregui expone en el Discurso poético : el poema es la ejemplificación de sus teorías. Por ello no resulta válido plantear los términos ni desde la posición de los cultos, ni desde la de los claros, sino desde la propuesta por Jáuregui, pues todo lo que en el Orfeo realiza está fundamentado teóricamente en el Discurso. » (J. de Jáuregui, Discurso poético, Madrid, Editora Nacional, 1978, pp. 22-23) Juan Matas corrobora : «... el Orfeo de Jáuregui se publicó en 1624, junto al Discurso poético, compartiendo ambas obras, en un único volumen, las pertinentes aprobaciones, anécdota que ha permitido conjeturar que las dos creaciones nacieron con la pretensión de ejemplificar, desde la doble perspectiva teórico-práctica, la idea que Jáuregui tenía de la poesía, una concepción que debía manifestarse en esa doble trinchera de la teoría y de la praxis para salir a la palestra del turbulento panorama literario en que todos se sentían involucrados. » (« Una nota sobre el Orfeo-Ut musica poesis- de Juan de Jáuregui », Espada del Olvido, ed.cit., pp.183-197, cita p. 197)

52 Rechifla procedente de algunos partidarios de Góngora pero sobre todo del círculo de Lope de Vega 
y misceláneos, contienen, además de las fábulas que les dan título, otras fábulas, numerosos textos en verso y en prosa, autorretratos, apologías pro domo, confidencias, piezas de adulación cortesana, cartas a amigos y aliados, novelas, ensayos sobre la "nueva poesía". Son pequeñas galaxias de las que Lope de Vega pretende hacer el espejo de su persona y la culminación de su obra. También las fábulas de Faria y Sousa, impresas en los mismos años ${ }^{53}$, se relacionan con reflexiones teóricas y críticas sobre la poesía. Además, muchos de estos textos están dedicados al Conde-Duque de Olivares o a miembros de su familia y de su clan ${ }^{54}$, en un momento en que la gloria del ministro ha alcanzado su cenit y en que se puede aguardar todo de un mecenazgo que todavía no ha desalentado ninguna esperanza. La fábula está pues vinculada con la crítica y la teoría poéticas, en unos breves años de controversia apasionada sobre cuestiones formales ${ }^{55}$, en que los eruditos argumentos en torno a la imitación poética, al mejor estilo, a la dificultad y a la oscuridad legítimas o ilegítimas, son armas arrojadizas en la lucha de individuos y grupos por el prestigio literario. La fábula, que fácilmente

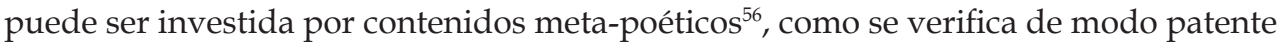

y muy premeditada puesto que el Orfeo en lengua castellana, en cuyo texto y preliminares abundan las alusiones maliciosas al Orfeo de Jáuregui fue impreso en los mismos días que éste. La tasa de la edición del Orfeo lleva la fecha del 12 de Agosto de 1624 y el Orfeo en lengua castellana tiene un privilegio fechado el 27 de agosto y una censura fechada el 13 del mismo mes. Sobre toda la polémica del Orfeo, véase J.M. Rico García, La perfecta idea de la altísima poesía. Las ideas estéticas de Juan de Jáuregui, Diputación de Sevilla, 2001, pp.222-234.

53 Manuel de Faria y Sousa, Divinas y humanas flores, primera y segunda parte, Madrid, por Diego Flamenco y a su costa, 1624. El libro, dedicado al duque de Alcalá, lleva un soneto liminar encomiástico de Lope de Vega, y un prólogo de tono malhumorado y sarcástico (muy típico del autor) en el que hace acto de homenaje a Camões y a Lope y se burla de los cultos, declarándose pues en contra de Góngora y sus admiradores y secuaces. Sin embargo la "Fábula de Apolo y Dafne" contenida en el mismo libro, y a decir verdad no demasiado lograda, debe mucho al ejemplo del Polifemo y a Góngora en general.

54 No pretendemos aquí agotar el tema y daremos sólo unos ejemplos. Juan de Jáuregui dedica a Olivares su Discurso poético y su Orfeo. Lope dedica en el año clave de 1621 la Filomela a doña Leonor Pimentel, de la casa del duque de Benavente, don Juan Alonso Pimentel. Ahora bien, la madre de Olivares, doña María Pimentel, pertenecía a la misma familia, y el duque de Benavente era, según Elliot, el segundo miembro prominente del régimen instaurado después de la caída del clan Lerma, y cuyo primer miembro era don Baltasar de Zúñiga, tío y aliado de Olivares (John H. Elliott, The Count-Duke of Olivares. The Stateman in an Age of Decline, New Haven and London, Yale University Press, 1986, p. 81). El mismo libro, La Filomena, contiene un poema (La Mañana de San Juan en Madrid) dedicado al conde de Monterrey, cuñado de Olivares, y que tendría durante sus gobiernos los cargos más codiciados. En cuanto a La Circe, Lope la dedica a Olivares mismo; dentro de la miscelánea de ese título, « La rosa blanca », que agrupa los mitos centrados en Venus, está dedicada a la hija de Olivares, María de Guzmán. Todavía en 1639, Soto de Rojas le dedica al mismo ministro Los rayos de Faetón.

55 Este momento de pasión teórica en torno a cuestiones específicamente literarias que coincide con la polémica sobre la novedad gongorina es de duración relativamente breve y resulta tan interesante por ser más bien excepcional en la historia de la cultura española. Su declinación podría estar ligada, en un primer momento, al ambiente más sombrío que reina en España a partir de los años 1630, por razones económicas, militares y políticas y, a más largo plazo, al triunfo de los partidarios de Góngora.

56 El que hablar de Orfeo sea ocasión o pretexto para hablar de poesía y de poética resulta particularmente obvio en el Orfeo en lengua castellana. En el tercer y último canto, la circunstancia de que Apolo devuelva a Orfeo su lira -que éste había destrozado al salir del infierno como un juguete inservible- sirve de pretexto para una digresión que incluye un catálogo encomiástico de los ingenios españoles, un 
en el caso de Orfeo, patrón de la poesía, parece ser por entonces la posición en torno a la cual se combate, el terreno en que un poeta puede esperar prevalecer sobre sus rivales.

\subsection{Ovidio en la edad de la polémica gongorina : recrear las "Metamorfosis"}

Esta posición privilegiada del género fábula tiene por necesario correlato la atención prestada a la obra de Ovidio, fuente principal del material mitológico. Pese a la originalidad del Polifemo de Góngora, tanto en la construcción del relato como en la concepción de la escritura, y pese a su deuda con un poeta moderno como Tommaso Stigliani ${ }^{57}$, el argumento y la visión del personaje principal arrancan principalmente de Ovidio y no de Stigliani o de Marino, como tampoco de Homero, Eurípides, Teócrito, Luciano o Virgilio. Podría mostrarse lo mismo a propósito de las fábulas de Jáuregui, Lope de Vega, Villamediana y demás cultivadores del género. Ciertamente una de las novedades del poema gongorino reside en la práctica de una imitación que opera una síntesis inédita a partir de materiales hallados en tratamientos anteriores no ya de la fábula misma sino de cada motivo tocado por el relato. No se trata simplemente de zurcir fragmentos que son traducción libre de distintos poetas, de acuerdo con la práctica de las mejores fábulas renacentistas, sino de fundir, en cada instante del discurso, creaciones expresivas, figuras, conceptos que proceden de diversas fuentes. El poeta somete sus fuentes a una transformación integradora después de haberlas previamente desmenuzado y asimilado de modo que es a menudo difícil o imposible decir con precisión si está realmente imitando unos versos o simplemente tratando un tópico o prolongando un cauce trazado por la tradición. Para decirlo simplemente, mientras que Aldana o Hurtado de Mendoza escribían teniendo bajo los ojos el texto de Ovidio, o habiéndoselo previamente aprendido de memoria, Góngora parece haberlo leído con detenimiento y medio olvidado cuando escribe su fábula. Jáuregui opera del mismo modo. En todo momento parecen combinarse en su memoria distintos tratamientos poéticos de la historia de Orfeo, Ovidio, el Virgilio de las Geórgicas y de la Eneida, los italianos ; deja aflorar además breves reminiscencias de muchos textos no relacionados con su tema.

En su famosa carta a Góngora, el helenista Pedro de Valencia proponía a su corresponsal imitar a Homero, volver a los griegos, liberar al poeta moderno de su

\footnotetext{
« Parnaso » o « Laurel de Apolo » en miniatura (Canto III, oct. 24 a 38).

57 Léase sobre este punto el definitivo trabajo de Giulia Poggi, «Mi voz por dulce, cuando no por mía : Polifemo entre Góngora y Stigliani », Góngora Hoy VII. El Polifemo, ed.cit., pp. 53-74. También puede resultar de interés la sección titulada "Un complejo diálogo con la tradición: invención gongorina y materia polifémica", que Jesús Ponce Cárdenas incorpora a su amplia introducción a la Fábula de Polifemo y Galatea, Madrid, Cátedra, 2010, pp. 33-61.
} 
deuda asfixiante con la poesía italiana e incluso latina ${ }^{58}$. Es posible que Lope de Vega haya sido sensible a llamamientos de este orden, y haya pretendido en La Circe, más allá de Ovidio y de Virgilio a quienes debe la materia de su poema, aproximarse a Homero, a los remotos e imponentes orígenes de la poesía.

Este nuevo tipo de "imitación", si todavía puede llamarse así, que predomina en el Barroco es uno de los factores que contribuyen al nuevo interés del género fábula. Gracias a la libertad alcanzada al despegarse de un modelo, es posible tratar la urdimbre narrativa del mito como cosa propia, como una materia a la que pueden incorporarse conceptos forjados en el acto mismo de escritura. Sin embargo ninguna fuente clásica consigue contrapesar, en lo que respecta a la materia mitológica, a Las Metamorfosis, sin duda porque en ningún otro texto se da tal cantidad de material fácilmente asimilable, dispuesto a convertirse en common knowledge y, al mismo tiempo, elaborado con el vigor y el refinamiento de la gran poesía.

Por ello, en ese momento de efervescencia provocado por la novedad gongorina, Ovidio se convierte en una referencia primordial. En los años 1620 en que escriben Lope y Jáuregui, el influjo de Góngora se combinó con otros, en especial con el de la poesía de Marino, los ocho Idilli favolosi, publicados en La Sampogna en $1620^{59}$, y el Adone difundido parcialmente en España antes de su primera impresión de $1623^{60}$. Pero el Adone es un poema que crece como un organismo monstruoso a partir de un poemita de dimensiones modestas, devorando todos los proyectos abandonados de su autor, una Gerusalemme distrutta, una serie de ékphrasis que debían completar la Galeria, una Polimnia (poema enciclopédico) y sobre todo un poema titulado Le Trasformazioni, donde, en expresión del propio Marino, "se habrían explicado todos los arcanos de la filosofía oculta bajo la amenidad de tal vez ocho mil fábulas". El Adonis resulta pues entre otras cosas de la ingestión de un poema concebido para emular Las Metamorfosis, a base de entrar a saco también en otros vastos frescos mitográficos que ofrecía la poesía helenística, menos frecuentados y agotados que el de Ovidio, como los de Claudiano o Nono de Panópolis.

58 M. M. Pérez López, Pedro de Valencia, primer crítico gongorino. Estudio y ed. anotada de la "Carta en Censura de sus poesías." Universidad de Salamanca, 1988.

59 Véase la excelente edición de V. De Maldé, G.B. Marino, La Sampogna, Parma, fondazione Pietro Bembo-Ugo Guanda Editore, 1993. Villamediana sigue de muy cerca el « idillio favoloso Europa » de Marino en su Fábula de Europa, como lo señaló Juan Manuel Rozas, « Marino frente a Góngora en la Europa de Villamediana (con una nota sobre el cultismo gongorista)", en Homenaje al instituto de Filología y Literatura Hispánicas « Dr. Amado Alonso », en su cincuentenario, Buenos Aires, 1975, pp. 372-385. El trabajo de J. Ponce « Sobre amplificatio y minutio : el rapto de Europa en los versos de Marino y Villamediana » Il Confronto letterario, XVII n. 33, 2000, pp.127-147, compara con precisión ambos poemas.

60 Para la conjugación de la influencia de Góngora con la de Marino, véase Juan Manuel Rozas, Sobre Marino y España, Madrid, 1978. 
A sus detractores que le reprochan la irregularidad fantástica del poema y lo comparan con Ovidio, Marino contesta celebrando con entusiasmo la fantasía de las Metamorfosis que él, Marino, soñaría con igualar ${ }^{61}$. La estética del cantor de Adonis es pues expresa y provocativamente ovidiana y el influjo de su gran poema en España contribuye a renovar el atractivo del poeta latino. Pero, a la inversa de lo que ocurría en el siglo XVI, se trata ahora menos de seguir paso a paso el orden de los relatos de Ovidio, que de inspirarse de su ejemplo, con alardes de audacia en la concepción y ejecución. La nueva poética ovidiana al modo de Marino se traduce por un relato abierto y polifónico, donde el desorden aparente encubre o parece encubrir un orden complejo. El Adone conjuga la ambición de un poema narrativo universal, donde están incluidos todos los grandes esquemas narrativos posibles, al menos los que son conciliables con las actividades y preocupaciones de la paz, y el propósito enciclopédico de un poema que enseña todo lo que hay que saber sobre la naturaleza, sobre el arte, sobre las pasiones, sobre los dioses. Esta empresa podría recordar al Ovidio alegórico medieval. Pero entre el Ovidio moralizado de la Edad Media y los significados profundos y complejos a que aspiran los poemas barrocos hay una diferencia: además de prescindir por lo general de la teología cristiana, los autores de fábulas barrocas saben que estos significados enciclopédicos son producto del ingenio y no una propiedad inherente a las historias que reelaboran.

Los precedentes muy distintos entre sí que constituyen Marino y Góngora animan a imitar no ya la letra de Ovidio, sino su designio de conjunto, filtrado por una interpretación. Siguiendo sus huellas, los poetas pretenden apropiarse del fondo impersonal del mito, marcarlo con su impronta, organizar mediante él su propio mundo. De ahí que nos encontremos con importantes referencias a Ovidio en la era de la polémica en torno a Góngora. La primera y más conocida se encuentra en la "carta en respuesta" atribuida al poeta, que debe su fama al hecho de ser casi el único texto "teórico", valga la palabra, de Góngora, tal vez el poeta español que más discurso crítico ha provocado y a un tiempo el menos propenso a explicarse sobre la producción poética propia y ajena. En esta carta, editada y estudiada en un artículo de Antonio Carreira, figura el famoso párrafo:

Pregunto yo ¿han sido útiles al mundo las poesías y aun las profecías (que vates se llama el profeta como el poeta)? Sería error negarlo, pues dejando mil exemplares aparte, la primera utilidad en ellas es la educación de qualesquiera estudiantes de estos tiempos ; y si la obscuridad y estilo intricado de Ovidio (que en lo de Ponto y en lo de Tristibus fue

61 "Voi l'intitolate poema fantastico e fuor di regola e dite che non puo cadere la comparazione [fra l'Adone e la Liberata] perche sarebbe come voler rassomigliare l'Eneide alle Metamorfosi. Adunque, secondo voi; di necessità si segue che quello delle Metamorfosi sia poema irregolato e fantastico. Ma perché non voglio esser lapidato dai fiutastronzi et dei caccastecchi, mi basterà dire che troppo bene avrò detto che le poesie d'Ovidio son fantastiche, poichè veramente non vi fu mai poeta ne vi sarà mai, che avesse, o che sia per avere maggior fantasia di lui. Et utinam le mie fossero tali.". Citado por Marzio Pieri en Giambattista Marino, Adone. Bari, Laterza, 1977, tomo II, p. 759. 
tan claro como se save y tan obscuro en las Transformaciones) da causa a que, vasillando el entendimiento en fuerça de discurso, trabajándole (pues crece con qualquier acto de calor) alcanse lo que en la letra superficial de sus versos no pudo entender luego, hase de confessar que tiene utilidad avivar el ingenio, y esso nació de la obscuridad del poeta. ${ }^{62}$

Esta página, pese a su aparente sencillez, presenta numerosos problemas, y ante todo el de saber si Góngora bromea o si habla en serio ${ }^{63}$. La oscuridad que le atribuye a Ovidio en Las Transformaciones, dio pie a una curiosa nota de Francisco Rico, “El gongorismo de Ovidio" ${ }^{64}$. Rico recuerda que Ovidio, lejos de ser tenido por difícil y oscuro, pasaba por parangón de llaneza y de facilidad lingüística, no menos en las Metamorfosis que en el resto de su obra. A Rico se le ocurre entonces la idea peregrina de que Góngora, estudiante disipado y aficionado al juego, la música y los espectáculos, tal vez tuviera del latín un conocimiento superficial. Su sintaxis latinizante sería el fruto paradójico de su fascinación por un latín descifrado con dificultad, un resabio de alumno brillante y perezoso al que le cuesta hallar el orden recto tras el orden trastocado de las cláusulas latinas, felix culpa, sin embargo, concede en su conclusión el crítico. La hipótesis es deliciosa por lo iconoclasta y ninguno de los ataques a Góngora por sus contemporáneos llegó a tal extremo de impertinencia. Nos resistimos a aceptarla porque la poesía de Góngora deja traslucir un conocimiento maduro de los clásicos y además la frase incriminada que opone un Ovidio fácil, el de las elegías, y un Ovidio difícil, el de las Metamorfosis, no se explicaría si el redactor de la carta aludiese a los escollos del latín para un estudiante perezoso.

Bastante más plausible parece la interpretación de Ulrich Mölk, que observa que también Sánchez de Viana menciona la oscuridad de Ovidio ${ }^{65}$. Para el traductor de las Metamorfosis, las "obscuríssimas tinieblas" de su poeta consisten no en el hermetismo de la letra, puesto que el latín de Ovidio no tiene nada de recóndito, sino en la supuesta profundidad del sentido espiritual o alegórico. Mal entendiendo adrede o no a sus detractores, Góngora atribuye la oscuridad que le imputan no a lo insólito de la sintaxis, del vocabulario o de las figuras, sino a una doctrina encubierta

62 A. Carreira, "La controversia en torno a las Soledades. Un parecer desconocido y edición crítica de las primeras cartas" en Hommage a Robert Jammes I, Anejos de Criticón, Toulouse, PUM, 1994, p. 151-171. Artículo que recoge más tarde Antonio Carreira en su importante colectánea Gongoremas, Barcelona, Península, 1998.

63 Las inconsistencias y disparates (aparentes al menos) de la carta son de tal naturaleza que Antonio Carreira tiende a restar importancia al texto. Sin embargo disiente respetuosa pero abiertamente de Robert Jammes, cuando éste llega a dudar de su autoría. En nuestra opinión también esta duda es excesiva porque se funda sólo en la idea que nos hacemos de la personalidad y cultura de Góngora. Véase "La polémica de las Soledades (1613-1666). Catálogo", en Luis de Góngora, Soledades, ed. de R. Jammes, Madrid, Castalia, 1994, 614-616.

64 F. Rico, “El gongorismo de Ovidio" en Primera Cuarentena, Barcelona, 1982.

65 U. Mölk, "Góngora und der dunkle Ovid" en Archiv für das Studium der neueren Sprachen, CCIII, 1966-67, p. 415-27. 
y misteriosa. El Polifemo, precisamente por ser una verdadera variante del mito, como lo son los textos de Ovidio, y no la simple paráfrasis de un texto preexistente, da pie a lecturas orientadas hacia la búsqueda de estratos latentes de significado. Dos libros relativamente recientes, Gongora, percorsi della visione, de Enrica Cancelliere, de 198866, y Cyclopean Song : Melancholy and Aestheticism in Góngora's Fabula, de Kathleen Hunt Dolan $(1990)^{67}$, son muestras del resultado, sugerente, al que pueden llevar tales indagaciones.

Se trata en definitiva, en el nuevo género de la fábula tal como lo inaugura Góngora en España, no de una mera paráfrasis más o menos diestra de Ovidio, sino de una tentativa de emular a Ovidio y a los antiguos narradores de mitos, apropiándose de la materia mitológica para acceder a unos significados más exquisitos o profundos, no limitados a lugares comunes de la poesía amorosa o heroica. El Adone de Marino, aunque tan distante de Góngora, contribuye a alentar esas ambiciones. Se trata de hacer propia la “fábula común' como escribe el más precoz e inteligente de los anotadores de Góngora, Díaz de Ribas, defendiendo las libertades que se toma Góngora con el argumento clásico. Como él observa, en las fuentes antiguas el cíclope conoce desde el comienzo los amores de Acis y Galatea. En cambio, en la fábula de Góngora, los dos se enamoran justo antes de ser descubiertos por Polifemo que, en su rabia insana, mata en seguida a Acis. Por ello el canto del fiero cíclope brota sólo del amor y no de los celos como en Ovidio. Tenemos pues un tajante y sabroso contraste entre la dulzura del canto del cíclope, verdadero néctar, de creer a Díaz de Ribas, y el furor asesino que se apodera de él al descubrir accidentalmente a los amantes. Estas y otras licencias no sólo deben admitirse sino que deben aplaudirse como "gala" y "bizarría":

Pero licencia es frecuentísima en los poetas el variar las fábulas y solo atender a hablar con propiedad y verosimilitud, y es cierto género de gala el hacer esto disponiéndolo con nuevos colores de invención, con que la fábula común se hace como propia. ${ }^{68}$

A nuestro entender, las octavas iniciales de la Circe de Lope, son sintomáticas de esa nueva postura frente a las fábulas. Una postura que, al hacer imperativa la libre invención del poeta, autoriza un afán de "gala", de novedad y brillantez, y por ello supone una poética más exigente, un empeño de mayor gravedad:

Tú, que del sacro artífice del oro científica y hermosa, procediste, Circe, que al blanco cisne, al rubio toro en variedad de formas excediste,

66 E. Cancelliere, Góngora, percorsi della visione, Palermo, Flaccovio, 1988.

67 K. Hunt Dolan, Cyclopean song. Melancholy and Aestheticism in Góngora's Fábula de Polifemo y Galatea. Chapel Hill, North Carolina U. P., 1990.

68 Anotaciones al Polifemo, ms. 3906 de la B.N. Madrid, nota 92, f. 127. Tomamos la cita del artículo de M. Romanos , « Los tan nuevos y peregrinos modos... », ed. cit., p. 223. 


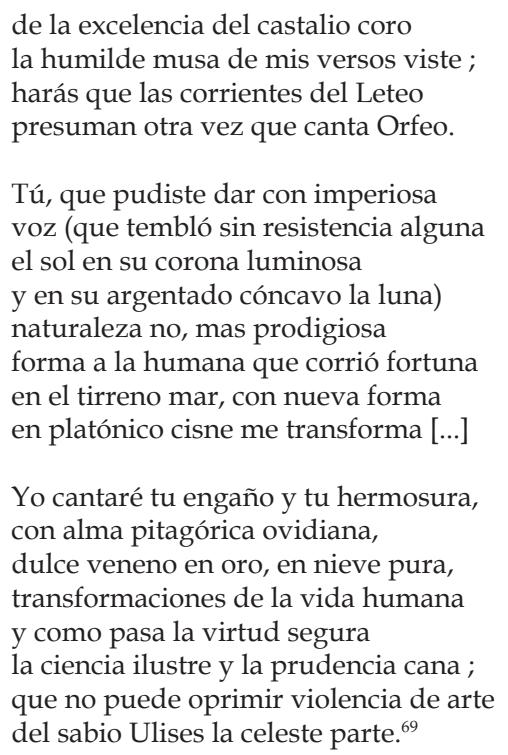

Dámaso Alonso reconoció en el nuevo gusto que aparece en el Lope de estos años, y que se hace patente en versos enrevesados y solemnes como los que acabamos de leer ${ }^{70}$, una réplica a la admirada oscuridad de Góngora. Por lo demás, resulta obvio para un lector de Ovidio que las referencias a este poeta no se limitan a la mención explícita "ovidiana" sino que recorren las tres estrofas, desde la hipérbole que pondera los poderes mágicos de Circe, hasta la referencia a Pitágoras, filósofo cuyo discurso concluye las Metamorfosis. Una lectura más atenta del fragmento y de su contexto lleva a pensar que este preludio expone la clave del poema. Lope escribe su exordio como una réplica a Góngora, un argumento ad hominem. Yo también, parece decir Lope, aspiro a reanudar con la empresa de Ovidio, no de tu Ovidio frívolo y vacío de sustancia, sino del filósofo pitagórico, doblemente respetable. Respetable porque la ciencia pitagórica explica las apariencias cambiantes del universo físico, sometidas al arte de Circe, dominio de la alquimia, la magia y la sensualidad, y respetable porque la sabiduría de Pitágoras conduce, más allá de este mundo de sombras y reflejos, hacia la esfera superior e inmutable donde son acogidos apoteósicamente el sabio Ulises y cuantos militan con él bajo la blanca bandera del cisne platónico. De modo acorde con tan ambicioso designio, en un estilo atormentado por reminiscencias de Góngora, Lope se propone en su Circe escribir una fábula ejemplar, un triunfo de la castidad y del amor espiritual, del que Ulises sería el inesperado modelo. El Ulises de Lope, firme en su fidelidad patriótica y conyugal, asiste imperturbable al despliegue de los

69 La Circe, oct. 1-2 en Lope de Vega, Obras poéticas I. Barcelona, Planeta, 1969, p. 937.

70 Véanse las secciones tituladas «Lope gongorista » $\mathrm{y}$ « Lope poeta filosófico » en el fundamental ensayo de D. Alonso, "Lope de Vega, símbolo del Barroco », Poesía española. Ensayo de métodos y límites estilísticos, Madrid, Gredos, 1987 (1a ed., 1950), pp. 417-478. 
encantos de Circe, que no son todavía los "encantos de la culpa", como en el auto de Calderón, pero si los encantos del afeite, de la apariencia, del arte como estímulo erótico, del teatro, y de la metamorfosis.

La interpretación de las Metamorfosis en términos de "filosofía natural", de enciclopedia cosmográfica, y el deseo de injertar en una sola fábula la totalidad de la enciclopedia, también se manifiesta en el Orfeo en lengua castellana. Unas octavas presentadas como muestra del sublime canto de Orfeo están manifiestamente inspiradas por el comienzo del libro I de las Metamorfosis :

Cantó como se buelve en ayre el fuego,
y en fuego el ayre, el agua evaporada
en ayre, y como condensado luego
se buelve en ayre el agua dilatada :
y cómo el agua pura hallò sossiego
en tierra por lo denso transformada,
concurriendo los quatro a toda forma
de cuerpo misto que su junta informa $[. . .]^{11}$

Después de su salida del infierno, el Orfeo en lengua castellana, como lo hacía también el Orfeo de Ovidio, canta los afectos de amor y de hecho, una serie de metamorfosis ovidianas. En unas pocas estrofas se condensan las historias de Cipariso, Tifonte [sic], Ganimedes, Jacinto, Pigmalión, Mirra, Adonis, Hipomene y Atalanta. Por un concepto quizá demasiado ingenioso, las plantas que, como quiere la tradición, se arrancan a sí mismas de raíz para agruparse en torno a Orfeo, atraídas por la magia de su canto, son los mismos héroes cuya transformación en planta él está cantando y que se acercan a él para llorar sus propios amores perdidos, "el eco dulce" de su "historia triste" :

$$
\begin{aligned}
& \text { No menos flor hermosa, que ya fuyste } \\
& \text { alma bella de Adonis, te acercaste } \\
& \text { al eco dulce de tu historia triste } \\
& \text { y los granos en lagrimas trocaste : } \\
& \text { Tu que para matar de amor naciste } \\
& \text { a la madre de Amor, y me vengaste, } \\
& \text { supiste de su Lyra que secreto } \\
& \text { hijo te hizo de quien fuyste nieto. }
\end{aligned}
$$

De modo que Orfeo, el poeta absoluto y maestro de toda poesía elevada y ambiciosa, es para Lope-Pérez de Montalbán el mismo Ovidio revestido con ropajes heroicos y mitológicos ${ }^{72}$.

71 Juan Pérez de Montalban, Orfeo en lengua castellana, ed. de P. Cabañas, Madrid, CSIC, 1948, p.28.

72 Sobre este punto, el autor del Orfeo en lengua castellana no hace sino interpretar al mismo Ovidio, quien construye al personaje de Orfeo no sólo como poeta por excelencia, sino como una figura de lo que él mismo aspira a ser o sea, de su propia poética. Jacqueline Fabre-Serris, en su tesis sobre « mito y poesía en las Metamorfosis », habla a este propósito de jeux de miroir.(J. Fabre-Serris, Mythe et poésie dans les Métamorphoses d'Ovide. Fonctions et significations de la mythologie dans la Rome augustéenne, Paris, 


\subsection{La fábula como matriz de conceptos sublimes}

En suma, los rivales de Góngora se proponen un nuevo tratamiento de la fábula, tan monumental y tan libre como el del Polifemo, pero del que broten sentencias morales y filosóficas. Jáuregui parece querer mostrar en su Orfeo que la vehemencia sublime de la escritura, de la que abusa según él Góngora para informar conceptos vacuos o superficiales, debe justificarse por la seriedad del pensamiento. Como la de Ulises revisada por Lope, la historia de Orfeo en Jáuregui es una historia de sublimación. Con sutiles pinceladas, Jáuregui da a entender que Orfeo es el Poeta por excelencia porque es el más desdichado de los hombres, desdichado por vocación y presentimiento antes de haber perdido lo que de antemano adivina que nunca poseerá con felicidad. La "difícil perspicuidad" que defiende el poeta en su Discurso poético cobra en su fábula los tintes lóbregos del Averno al que desciende el héroe en busca de su esposa muerta. El poema expone y aplica una doctrina poética en los antípodas de la enigmática frivolidad gongorina. Una entereza estoica, la memoria de los muertos y de la muerte, la melancolía y la impasibilidad, la novedad que brota incesante, rompiendo con valentía la monótona regularidad natural, la vigilancia severa de una implacable disciplina formal, caracterizan a Orfeo como personaje y artista, sobre todo en lo que Jáuregui presenta como momento de madurez de su arte, el momento que sigue a la segunda pérdida de Eurídice, cuando la tierra le parece a Orfeo continuación del infierno :

El dolor y tristeza, que rendido
el mustio cuello, en opresión severa,
sus triunfales despojos fueron antes,
ya indómitos le oprimen y triunfantes.
De aquel pecho al antiguo señorío
se restituyen con rigor más fiero:
tal se conduce del lugar sombrío
al superior espléndido hemisfero.
No el cambio de lugares, no el desvío
mudanza fue del padecer primero,
antes continuación no interrumpida
de infierno igual y sombra aborrecida. ${ }^{73}$

El arte musical de Orfeo, opuesto al arte del "músico jayán" a cuyo "fiero canto" está dedicado el Polifemo, procede de un dolor inamovible, que ninguna empresa heroica puede ya aliviar. Es un arte ideal en cuanto, asentándose sobre el incurable dolor del artista, procura un éxtasis del que todo el universo participa: un voluptuoso olvido de sí, una suspensión del dolor en todas las almas tocadas por el canto y en los seres inanimados e irracionales, una infusión del espíritu, como si la voz de Orfeo

Klincksieck, 1995).

73 Orfeo, canto III, versos 325-336. Juan de Jaúregui, Poesía, ed. cit., pp. 515-516. 
los fecundase con el soplo de la razón. Como escribe famosamente Jáuregui : “Allí naturaleza sus precetos / rompe, no se limita en ley alguna : / ondas peñascos, plantas, animales/ de voz conciben almas racionales." ${ }^{\prime 4}$. La recompensa final es penetrar, más allá de los antros infernales, en los Campos Elíseos y en los abrazos de Eurídice :

\author{
Mas el heroico espíritu de Orfeo \\ venganzas contra ofensas no pretende \\ que, en alma ya feliz, grave deseo \\ ni altera afecto ni pasión enciende. \\ A las ínfimas ondas del Leteo \\ la vez segunda y última desciende ; \\ los sitios reconoce de su abismo \\ donde es también reconocido él mismo. \\ En los Elíseos reinos colocado \\ a Eurídice investiga cuidadoso \\ cuando su vista le atajó el cuidado \\ y fue su vista el colmo a su reposo. \\ Burlando ya de la invasión del hado \\ en sus abrazos se internó glorioso \\ donde anteriores padecidos males \\ hoy le sazonan gozos inmortales. ${ }^{75}$
}

Esta vuelta de Orfeo a los infiernos toma de Ovidio un desenlace que no se encuentra en Virgilio ni en los italianos, pero Jáuregui no escribe, como Ovidio, que en los Campos Elíseos, a veces Orfeo camina seguido por Eurídice, pero esta vez no teme volverse hacia ella ${ }^{76}$. Que el poeta sevillano suprima esta agudeza nos parece significativo de su deseo de evitar todo adorno frío y baladí. Un texto erizado de neologismos semánticos, un énfasis majestuoso y un estilo solemne en consonancia con la grandeza trágica del asunto, todas las características de estas últimas octavas son típicas del poema y de la ambición que lo inspira. Queda clara la lección estética del texto : un verdadero poeta debe poder extraer de la fábula antigua una doctrina sobre el arte mismo, en este caso sobre la inmensa dignidad y la fragilidad del artista ideal.

Los adversarios de Góngora le replican pues exhibiendo en sus versos lo que Góngora no ha sabido encontrar en Ovidio y lo que, según ellos, hubiera justificado la ambiciosa novedad de su escritura. Nada indica en efecto que Góngora haya querido encontrar en Ovidio una física y metafísica pitagóricas, una sublimación del erotismo o una apoteosis del arte. ¿Qué es lo que encontró que baste para dotar al relato mitológico de tan poderoso atractivo?

74 Orfeo, canto IV, vv. 1101-1104, ibid., pp. 494-495.

75 Orfeo, canto V, versos 329-344, ibid, p. 66.

76 «Invenit Eurydicen cupidisque amplectitur ulnis. / Hic modo coniunctis spatiantur passibus ambo, / Nunc praecedentem sequitur, nunc praevius anteit / Eurydicen suam iam tutus respicit Orpheus. » (XI, 63-66) 


\section{Magias del "Polifemo"}

\subsection{El arte de la ingeniosa condensación}

Una patente diferencia que separa a renacentistas y barrocos en su tratamiento de la fábula consiste en el método de la amplificación que, en el segundo caso, propende a dilatar el episodio mitológico para englobar en él otros muchos. Los materiales narrativos de la mitología considerada en su conjunto son puestos en perspectiva a partir de un episodio singular. Es evidentemente el caso del Adone, en que las más diversas historias penden como digresiones complejamente ramificadas de la trama de los amores de Venus. Algo parecido sucede en La Circe de Lope, que contiene entre otras muchas cosas el episodio ovidiano de Polifemo, o en el Orfeo de Pérez de Montalbán.

Góngora procede, a la inversa, por condensación. Como señaló Dámaso Alonso, su fábula da al paisaje siciliano, escenario de la aventura del Polifemo, una presencia no sólo decorativa sino funcional. En este paisaje la marca del mito está inscrita por doquier. Por referencia nominal, o por perífrasis, relatos simplemente aludidos brotan a partir de cada objeto nombrado. La comentadísima estrofa con que se inicia el relato es típica de ese modo de proceder :

Donde espumoso el mar siciliano
el pie argenta de plata al Lilibeo
bóveda o de las fraguas de Vulcano
o tumba de los huesos de Tifeo
pálidas señas cenizoso un llano,
cuando no del sacrílego deseo
del duro oficio da. Allí una alta roca
mordaza es a una gruta de su boca. ${ }^{77}$

Las historias de Tifeo y de Vulcano, no asociadas directamente a Polifemo en las fuentes clásicas de la fábula, son aquí brevemente tocadas. Lo que importa a Góngoraindependientemente del problema erudito de la errónea localización de la tumba de Tifeo o de la fragua de Vulcano bajo el Lilibeo-, parece ser la correspondencia de ambos mitos, fundada en una identidad de signos, las cenizas en el llano, que señalan un fuego escondido, un fuego subterráneo. No se sabe si se trata del fuego de la forja o del fuego del rayo, del fuego del deseo sacrílego o del fuego del trabajo fabril y el poema exige del lector no que escoja, sino que sume la eficacia poética de las dos historias. La huella visible, referencial, se materializa en una huella sonora, de esas que tan bien sabía sentir y describir Dámaso Alonso, ecos cavernosos de las vocales cerradas y los diptongos del verso 4, "o tumba de los huesos de Tifeo", martilleo de la fragua sugerido por la aliteración de la dental sonora, y por la fractura del verso 7 después de

77 Dámaso Alonso, Góngora y el "Polifemo". Madrid, Gredos, 1974, vol III, p. 14. 
un monosílabo : "deseo / del duro oficio da”. No sólo ambos mitos subterráneos entran en recíproca resonancia sino que los dos se proyectan sobre el héroe, Polifemo, que el poema vincula al mundo de la noche y de los poderes infernales. Lo infernal en sentido etimológico (lo subterráneo) y en sentido mítico (el mundo de los muertos) impregna la descripción de Polifemo y de su mundo, desde la boca de su caverna, semejante a las que aparecen en la iconografía del infierno y que, como la sima que da acceso al Tártaro, es "lecho oscuro" de "la caliginosa noche", hasta su cabello, "imitador undoso de las obscuras aguas del Leteo". El cíclope Polifemo es el hermano de los cíclopes que asisten a Vulcano y que trabajan con el fuego y los metales; como a los Gigantes lo anima un "deseo sacrílego", comparable al de Tifeo, hacia un objeto sublime de esencia celeste, Galatea. En muchos casos como el citado, los mitos rozados en figuras cuyo alcance es en apariencia descriptivo y decorativo aportan un delicado contrapunto al relato principal y crean un efecto de profundidad. Ese contrapunto es muy perceptible a veces, como en las asociaciones de Galatea con Venus o de Acis con Argos. A veces estas asociaciones laterales son menos evidentes, como en la siguiente estrofa:

Marítimo alción, roca eminente
sobre sus huevos coronaba, el día
que espejo de zafiro fue luciente
la playa azul de la persona mía ;
miréme y lucir vi un sol en mi frente
cuando en el cielo un ojo se veía ;
neutra el agua dudaba a cual fe preste
al cielo humano o al cíclope celeste. ${ }^{78}$

Según el comentario de Pellicer, "dice Polifemo aquí que un día estando la mar en calma, se miró en la Agua y vio un sol en su rostro y en el cielo un ojo : tan parecidos, que la Agua estava indecisa, sobre a qual avía de dar credito de Cielo, o Cyclope, si a Polifemo, porque le veía con el sol, le avia de tener por cielo, o al cielo por verle con un ojo le avia de creer por Cyclope."79

Vilanova ha desentrañado la serie de reminiscencias textuales, desde Ovidio y Virgilio hasta Juan de Mena y Stigliani, que asoman en esta estrofa ${ }^{80}$. Stigliani, en su poema de 1600, es el probable creador del concepto final que contrapone en un quiasmo a Polifemo, con su único sol en la frente, y al cielo que mira por su ojo único ${ }^{81}$. La dialéctica especular, a la que el concepto de Stigliani somete la analogía virgiliana

\section{Ibid., p. 30.}

79 José Pellicer de Salas y Tovar, Lecciones solemnes a las obras de don Luis de Góngora (1630). Olms Verlag, Hildesheim-New York, 1971, p. 320.

80 Vilanova, op. cit., vol 2, p. 583-608.

81 "E pur ha un occhio in faccia, io dico, il Sole / Con cui mira dai mori ai liti Eoi / Ei sotto'l mare, io nel mio scoglio il celo / Ei Polifemo grande, io picciol cielo" (Tommaso Stigliani, Il Polifemo. Milano, 1600, oct. 46.) 
y ovidiana entre el ojo de Polifemo y el sol, es típica del Barroco europeo ${ }^{82}$. Sólo en Góngora desemboca esa dialéctica en una especie singular de monstruo, el cíclope celeste $^{83}$ un efímero y fascinante mito personal, que llega a hacer monstruoso el cosmos en su presencia más cotidiana, el sol en mitad del cielo.

Como han observado los comentaristas, Alción es un personaje cuya transformación en ave marina se narra en las Metamorfosis ${ }^{84}$. La historia del naufragio del príncipe Alción, tal como Ovidio la cuenta, da pie a una grandilocuente descripción de tempestad en el mar, morceau de bravoure de rigor en toda epopeya. La asociación de los alciones a la imagen radiante de un mar color de zafiro no agitado por la más leve brisa, que se justifica por una creencia extendida en la Antigüedad ${ }^{85}$, descansa pues también, para los lectores de Ovidio, sobre un tácito contraste, del mismo modo que, en esa misma estrofa, la transfiguración celeste, el soleado azul del que se reviste Polifemo se perciben como una violenta recusación de los colores tenebrosos de su anterior descripción. La serenidad de la plaza azul, el cegador espejeo de los dos soles confundiéndose en su reflejo marino, esconden y muestran a la vez, como por deformación onírica, o representación por el término contrario, recuerdos de noche y de tormenta, el "proceloso viento" que peina la barba de Polifemo, la intensa negrura de su cueva y de su barba, la boca amordazada de la caverna, el sangriento agujero en que se convertirá, por obra del héroe vencedor de monstruos, el ojo de Polifemo.

Por lo tanto la capacidad de hacer resonar, a propósito de cada motivo, notas armónicas por analogía o contraste, nacidas de la puesta en contacto del relato principal con otros relatos tangencialmente evocados, constituye una de las novedades que introduce Góngora en el género fábula. Aunque el germen de este procedimiento se halla en Ovidio mismo y en la poesía antigua de gusto alejandrino, su desarrollo moderno requería una maestría, una confianza en el propio arte que nadie tal vez poseía como Góngora. De ahí que en su poesía la abundancia ornamental y descriptiva no impida la densa coherencia de la narración ${ }^{86}$. Los elementos descriptivos, lejos de ser decorativos y aislados, están semánticamente conectados con los motivos funcionales

82 Sobre ese punto, y aunque sin ejemplos españoles o italianos, me parece definitivo el artículo de G. Genette : "L'univers réversible" in Figures I, Paris, Seuil "Points", 1966, p. 11-28.

$83 \mathrm{El}$ « Polifemo grande » de Stigliani, como aposición a la palabra « cielo », es un mero chiste ; no tenemos una verdadera creación metafórica o producción de un objeto nuevo como en « cíclope celeste ».

84 XI, 474-572.

85 Como recuerda el comentario a esta estrofa de José María Micó, El « Polifemo » de Luis de Góngora, Barcelona, Península, 2001, p. 88 : « Un signo conocido de la calma del mar era, según los naturalistas y los poetas antiguos, la presencia del alción anidando sobre las aguas (lo dicen Eliano, Historia de los animales, I, 36 y IX, 17 ; Plinio, X, 89-91 ; Teócrito, VII, 57 ; Ovidio, Metamorfosis, XI, 745-748 ; Luciano, El alción, II), por no llegarnos hasta San Isidoro, XII, VII, o Juan de Mena, Laberinto, CLXXI.

86 En este sentido, puede consultarse el vario análisis comparatista del epilio gongorino que realiza Jesús Ponce Cárdenas en sus Cinco ensayos polifémicos, Málaga, Universidad de Málaga, 2009. 
del relato, como se ha mostrado en un reciente ensayo a propósito del zurrón repleto de frutas de Polifemo ${ }^{87}$.

\subsection{Valores simbólicos y valores visuales : el mundo como paisaje}

De estos vínculos nuevos, más o menos implícitos, creados entre los mitos o entre varios aspectos de un mito, en el marco de figuras microtextuales, surgen efectos de sentido ¿Estos efectos tienen un alcance filosófico, se orientan hacia una unidad de pensamiento, hacia una idea digna de ser apuntada por vías oblicuas y complicadas? Los contemporáneos de Góngora, cuando se hicieron este tipo de pregunta, contestaron negativamente. No había en Góngora misterios abstrusos, "sacramentos inefables", como escribe irónicamente Espinosa Medrano contestando a Faria y Sousa y otros detractores del poeta. No había en él nada más y nada menos que lo que puede esperarse legítimamente de un poema que no es "escritura sagrada": un rico tapiz de sonidos e imágenes animado por los destellos de refinadas alusiones y sutiles conceptos. En estos últimos años, los críticos han sido a veces más perspicaces o menos prudentes. Kathleen Hunt Dolan leyó el Polifemo no sólo con ayuda de Marsilio Ficino, sino también con la de Heidegger y Nietzsche. Para ella, Polifemo es un intelectual saturnino, y Galatea, el fascinante despliegue del mundo visible, presidido por Venus o incluso la elusiva Aletheia, la apertura del mundo, que desborda perpetuamente a los objetos con que el intelectual pretende colmarla. La interpretación de Enrica Cancelliere, de gran sutileza y erudición, es no menos ambiciosa y difícil. Partiendo de un comentario que concibe cada estrofa como un tableau, o sea una construcción plástica, un espacio poblado de formas y colores, un objeto tan visual como lingüístico o sonoro, esta estudiosa trata de demostrar que el Polifemo encierra un tejido de alusiones a mitos cosmogónicos, y mediante ellos expresa una concepción barroca, y por ello mismo moderna, del espacio donde la elipsis ha desplazado al círculo, y donde la anamorfosis ha desplazado la perspectiva del Renacimiento, frontalmente desplegada frente a un sujeto central.

Tal vez habrá quien juzgue estas exégesis más generosas, ingeniosas y entusiastas que rigurosamente razonadas. Lo que parece indudable es que, al elegir un fragmento de Ovidio, ya triturado por una multitud de imitaciones, para edificar su poética propia, Góngora propone un modo de leer la fábula antigua, y un modo de rehacerla, de ahondar en el mito. Esta lectura tal vez no es perfectamente entendida, como lo indica el revuelo en torno a su poema, porque difiere de las lecturas canónicas.

87 G. Mazzocchi, « La estructura narrativa del Polifemo », Góngora Hoy VII. El Polifemo, ed.cit. pp. 125136. 
Góngora no rehace la alegoría medieval, no encuentra en la aventura de Polifemo un sentido espiritual, verdad cosmológica, moral o teológica, confirmada por la fábula. Desde luego no sugiere que Galatea es el alma humana, Polifemo, el demonio, y Acis, Cristo, como lo hacen los redactores de autos sacramentales y de fábulas a lo divino. Tomando el mito como vehículo, emprende sin embargo una puesta en orden del mundo. Polifemo, el monstruo, alza su inmensa mole en el umbral entre el mar y la tierra, entre el infierno y el cielo. La prodigiosa Galatea, deidad marina como Venus, cisne de blancas plumas, se adorna del reflejo de todas las gracias celestes que simboliza el constelado "pavón de Juno". También recibe como ofrenda todo lo que crece en la tierra, la fastuosa y refinada cornucopia que vierten en la feraz Sicilia los campos, los montes y los bosques. Estas categorías, marino, terrestre, celeste, infernal, permiten ordenar el cosmos en un paisaje significativo en que personajes y objetos están hechos de una misma materia, como combinaciones de colores en una única paleta. Más obvio y fundamental es que estas categorías, al formar una red o sistema, confieren a los motivos del relato un significado provisional por medio de relaciones de identidad y oposición. Este modo de proceder nada tiene que ver con la exégesis medieval y evocaría más bien, si se consiente un paralelo aventurado, el método estructural de lectura del mito, y menos anacrónicamente, el método de Ovidio, que recompone a su modo la mitología griega, por la agrupación de las historias, por la contigüidad, el contraste y la analogía.

Este tratamiento de la "fábula" sorprende y a veces escandaliza en el siglo XVII. El escándalo es de orden estilístico y lógico ante todo. Se reprueba la oscuridad del texto y sobre todo la intolerable contradicción entre lo que deja esperar la expresión ardua y vehemente y un contenido insustancial, desprovisto de fibras morales. Como lamentaba Benedetto Croce refiriendo la observación a la literatura barroca en general, la única emoción humana inmediata que sin discusión comunica el poema es la emoción erótica, cuando invita al lector a compartir la delicia del encuentro, del silencioso cortejo y del inmediato abrazo entre dos amantes hechos a la medida del deseo, delicia más intensa cuanto más breve y más peligrosa. Pero hay algo más seguramente en el Polifemo que condimento refinado para un fantaseo erótico ${ }^{88}$. El Polifemo de los sonetos de Marino es un rústico cómico, un espantajo grotesco y presumido, atroz pero ligeramente enternecedor, un monstruo muy humano en suma, como lo era ya el Polifemo griego, en Teócrito o en Luciano. El Polifemo de Góngora no es una caricatura de ser humano sino algo más abstracto e imponente. En ese sentido se parece, más incluso que el de Ovidio, a un mito arcaico, a un haz de rasgos que se combinan narrativamente para plantear y resolver una relación antinómica, relación entre la música y la fiereza,

88 Se ha ocupado en deslindar los caminos sensuales de la compleja fábula barroca Jesús Ponce Cárdenas en El tapiz narrativo del Polifemo: eros y elipsis, Barcelona, Universitat Pompeu Fabra, 2010. 
los hábiles rodeos del arte y su impotencia frente a lo inmediato e incondicional del deseo.

Lope, Jáuregui, Villamediana, y los demás acogen algo de esta manera de proceder, con mayor o menor fortuna. La calidad plástica de las octavas del Polifemo, desarrollo conceptuoso de una o varias figuras retóricas, la atención al paisaje que sirve de fondo a la acción humana, la construcción de un espacio imaginario en torno a la figura, definido con nitidez en su arquitectura y sus colores, son innovaciones de Góngora que intentan asimilar sus competidores ${ }^{89}$. Así en este paisaje marino, condensado en una octava, que traza Villamediana, cuando su relato se detiene en contar el alba, semejante a cualquier otra, que precede al día fatídico de la carrera de Faetón :

Mueve nadante pez algoso asiento,
sale Tritón del caracol marino ;
próvido marinero esparce al viento
en cuadra forma el bien contexto lino ;
azota el remo al líquido elemento,
gobierna ya el timón y gime el pino,
y el confuso rumor de la cadena
es un teatro de la eterna pena. ${ }^{90}$

La estrofa, evocando el despertar del mar y el zarpar de la nave, suscita una impresión paisajística, efecto obtenido por medio de sinécdoques, de detalles fragmentarios yuxtapuestos, no pocas veces enigmáticos en cuanto obligan a restablecer conexiones elididas, como los galeotes aludidos en el verso 7, y por ello a colmar los vacíos del cuadro. Los cultismos dan relieve a estos detalles, alivian su posible trivialidad. Este boceto que podría titularse "estudio de un amanecer" suma notas visuales ("Mueve nadante pez algoso asiento", "en cuadra forma el bien contexto lino") y auditivas ("gime el pino", " el confuso rumor de la cadena"). No falta un epifonema con su acento patético y paradójico. El ciclo cotidiano que se reanuda cada mañana no aparece como apacible y grata rutina, sino que cobra la abrumadora monotonía de la "eterna pena", del castigo infernal. En este sentido los estragos que provoca el mal guiado carro de Faetón pueden interpretarse como efectos de una hazaña temeraria pero redentora. Aniquilar el mundo en un fuego purificador es también destruir el infierno y acabar con la pena y la muerte. Las técnicas de representación utilizadas y la posible alusión a un profundo significado de la fábula, proceden sin duda de Góngora, tanto o más que los cultismos o que los versos calcados del modelo.

89 Nuevos datos sobre la plasticidad del Polifemo ofrece Jesús Ponce Cárdenas en su introducción al poema: "Bajo el signo de la pintura: la enárgeia gongorina", en Fábula de Polifemo y Galatea, Madrid, Cátedra, 2010, pp. 71-94.

90 Versos 1057-1064. 
Una estrofa de Lope, en la Andrómeda, puede servir de muestra de técnicas descriptivas comparables utilizadas por el gran rival de Góngora. Así se relata la aparición del monstruo marino que amenaza a Andrómeda :

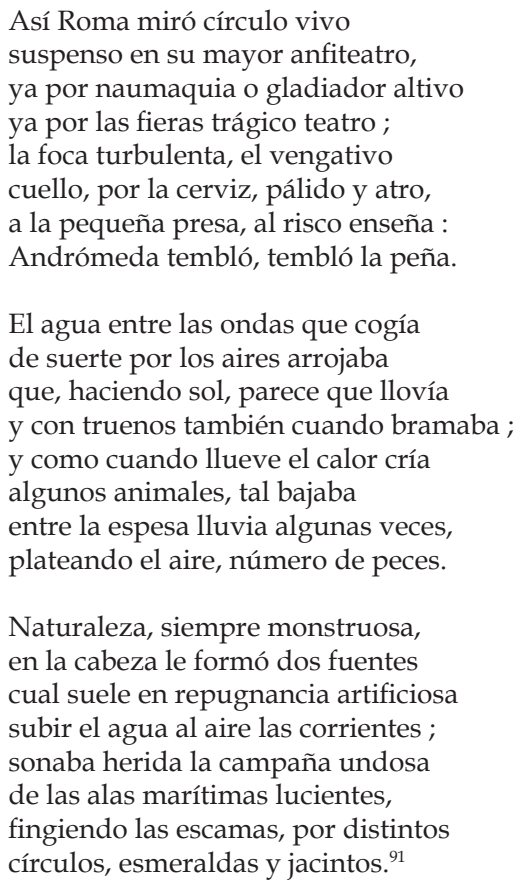

Estrofas hiperbólicas, que hacen del paisaje un teatro o más bien anfiteatro, una elipsis en cuyo centro se exhibe un resplandeciente monstruo, que no es otra cosa tal vez que la "naturaleza misma, siempre monstruosa", del mismo modo que el cíclope celeste no es otra cosa que el cielo. Como en ciertos fragmentos del Polifemo, el mito funciona en el lenguaje poético como medio o pretexto para trazar un paisaje a la vez naturalista y prodigioso, teatro para el inquietante dinamismo de los seres vivos y espacio de un espectáculo siempre admirable y con frecuencia sanguinario.

En los relatos inspirados por el tratamiento gongorino de la materia mitológica, cada motivo narrativo se despliega en un espacio paisajístico, en un cuadro a menudo vastísimo, como si la naturaleza fuera un fondo para la figura o como si de la figura misma se desprendiera un mundo permeable al lenguaje y al significado. Es posible que esta relación íntima entre figura y fondo sólo se halle en los relatos mitológicos, y en menor grado en otras narraciones poéticas, como la epopeya, donde la acción humana retiene toda o casi toda la atención. El canto IV del poema de Jáuregui consta

91 La Andrómeda, versos 585-608 en Lope de Vega, Obras poéticas, ed. cit. p. 742 
de una escena única, que narra lo inenarrable, profiere lo inefable, el canto de Orfeo ${ }^{92}$. El poema, que describe, de acuerdo con la tradición poética e iconográfica, a Orfeo cantando en un paraje natural y dictando a la naturaleza su armonía, asocia en estrecha unidad al paisaje que circunda a la voz y al paisaje invisible que reside en la voz misma. Jáuregui trata de hacer ver y vibrar el cosmos silencioso, apaciguado, extático, ya no externo a la voz, sino inherente a ella :

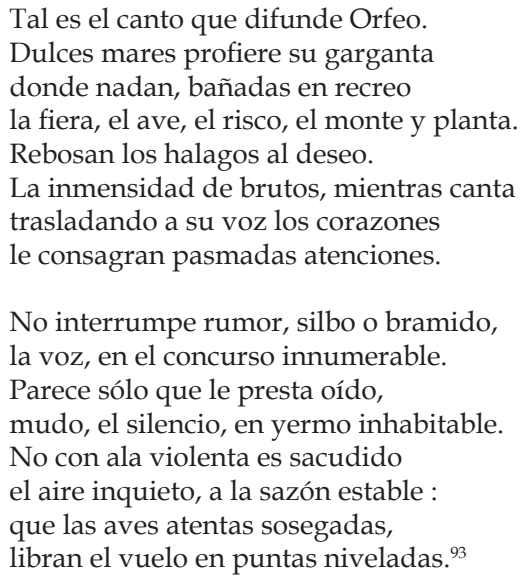

El mar de serena felicidad, el mundo silencioso y atento generado por la voz de Orfeo y que confluye hacia él, parece la réplica de Jáuregui al mar alterado, al mundo confuso y turbulento que suscitan en el Polifemo de Góngora la estridente zampoña y el "fiero canto" del jayán músico :

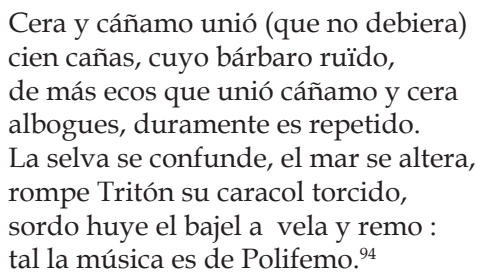

\subsection{El artista frente al Eros}

Lope y Jáuregui, al tiempo que tratan de apropiarse la manera gongorina, responden al escándalo que suscita, superponiendo a sus técnicas descriptivas, a su

92 Véase un sugerente análisis de este y otros pasajes del poema, interpretados como reflexión estética en J. Matas, « Una nota sobre el Orfeo -Ut musica poesis- de Juan de Jáuregui », La Espada del Olvido, ed.cit, pp. 183-197.

93 Orfeo, canto IV, versos185-200, p. 490.

94 Versos 89-96, Góngora y el "Polifemo", ed. cit. p. 17. 
modo de construir la narración y de amoldarla al marco de la estrofa, el lastre de lo moral y ejemplar, la gravedad de un pensamiento edificante. El Orfeo de Jáuregui y La Circe, que creemos el más ambicioso de los poemas mitológicos de Lope, son celebraciones de la castidad. Ulises se priva voluntariamente de los hechiceros encantos de Circe; no sólo desciende al infierno para que la bellísima maga le deje libre de volver a su esposa sino que, cuando ésta le reprocha sus "arrogancias y desprecios", él le responde pedantemente con un elogio del amor castamente divino:

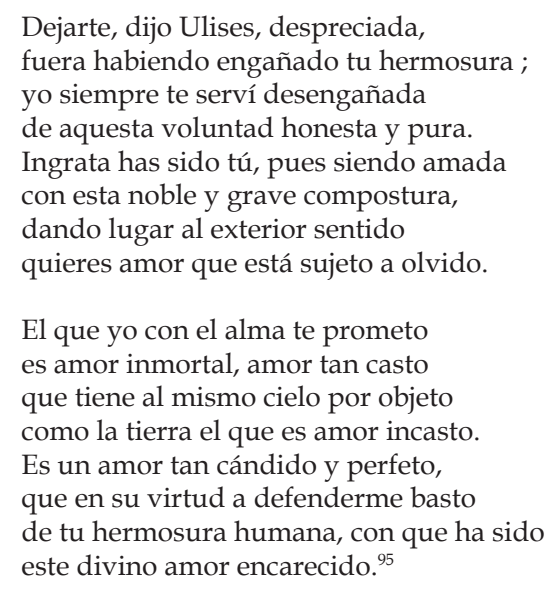

En cuanto al impecable Orfeo de Jáuregui, no sólo, como refieren las fuentes antiguas, irrita con su frialdad el furor de las Ménades sino que es desdichado por anticipación incluso en el lecho en el que vela con su amada :

\begin{abstract}
$¡ \mathrm{O}$, cuántas veces en igual desvelo los vio la noche y los halló la aurora ; $\mathrm{o}$, ya durmiendo, el vivo desconsuelo perseveró en el alma veladora! Sombras fabrica de estupendo yelo trágico el sueño, en invasión traidora : despiertan con temblor los corazones, sin repeler turbadas impresiones. ${ }^{96}$
\end{abstract}

En cambio, como lo ha mostrado Suzanne Varga en su estudio de los mitos en Góngora $^{97}$, éste acentúa los componentes eróticos de la fábula, al modo de Ovidio o de Marino, también al modo de Tiziano o Rubens, situándose en lo que para los españoles es un límite de la tolerancia dentro de la poesía grave. La descripción del encuentro de Acis y de Galatea es el núcleo de su fábula a la inversa de cuanto sucedía

95 La Circe, canto III, vv. 690-704?

96 Orfeo, canto I, vv. 89-96,, ed.cit., pp. 431-432.

97 Véase S. Varga, Mythes, mythographies et poésie lyrique au Siècle d'Or espagnol, Lille, Didier Erudition, 1984. 
en otras versiones del mito. La complaciente narración de la mímica que lleva en silencio a la ninfa y al fauno desde la primera mirada hasta el "tálamo", mímica que tiene algo de ritual o de danza, parecería en exceso lasciva si no la velaran los pliegues del estilo erudito y metafórico. Es escabrosa la situación de los amantes desnudos, que sólo una cortina de hiedra protege de la mirada de Polifemo, no de su voz aterradora. Los acentos del gigante incitan a la ninfa a abrazar a su amante con un ahínco en que se "anudan" e "implican" "amor" y "terror", "amor" y "temor":

\section{[...] la ninfa los oyó y ser más quisiera breve flor, hierba humilde, tierra poca que de su nuevo tronco vid lasciva muerta de amor y de terror no viva. \\ Mas-cristalinos pámpanos sus brazos- amor la implica, si el temor la anuda al infelice olmo que pedazos la segur de los celos hará aguda. ${ }^{98}$}

El efecto formidable de la voz de Polifemo, bajo cuya influencia el goce erótico parece cobrar intensidad frente a la inminente violencia, es también idealmente el efecto de la fábula y de la escritura poética de Góngora. Como genialmente escribe Díaz de Ribas, el mismo poema parece escrito por un gigante :

Nota bien la descripción del gigante y verás cuán grande y conveniente es, en la cual no sólo la pintura de las cosas corresponde a la magnitud del gigante, sino las voces y el gran espíritu y sonido de los versos, y aun todo este poema guarda este tenor que parece lo compuso un gigante. ${ }^{99}$

Algunos poetas, como Soto de Rojas en sus Fragmentos del Adonis ${ }^{100}$ o Bermúdez en su Narciso (pese a que lo dedique a su hermano, un franciscano) imitan la manera gongorina de velar un audaz fervor erótico con la elegancia erudita de la expresión. En cambio, el Orfeo de Jáuregui puede leerse como una réplica directa, por cuanto sitúa al artista, al poeta y músico, del lado de una costosa renuncia a los placeres amorosos. Lejos de ser verdugo, como Polifemo, en nombre del deseo y de los celos, Orfeo es víctima de un Eros femenino, el de las Bacantes, impúdico y bestial. En cuanto a la Circe de Lope y hasta cierto punto la Filomena, no sólo se inspiran de escritura de Góngora,

98 Vv. 349-56, ibid, p. .

99 Anotaciones al Polifemo, nota ${ }^{\circ} 86$, f. $125 v^{\circ}$. Citado por M. Romanos, “Los tan nuevos y peregrinos modos..", art.cit., p. 224.

100 Es significativo que los momentos más eróticos del poema de Soto (violación de Mirra por su padre Cinaras en el fragmento I, por cierto en contradicción flagrante con la narración ovidiana, amores de Hipomene y Atalante, en el fragmento VI) sean también aquéllos en que las reminiscencias literales de Góngora asoman con mayor evidencia.. Véase Fragmento I, vv. 131-146, vv.181-187, Fragmento VI, vv.1659-1676. 
sino que permanecen en el ámbito de interrogantes que afectan a las relaciones entre el erotismo, la belleza y el trabajo del artista.

\section{Conclusión}

En la moda de la fábula hay que ver -por supuesto- el cruce de muchos factores, algunos ciertamente sin relación con Góngora y que proceden de la poesía italiana y tal vez de la evolución general de la cultura. Sin embargo es muy probable que, como lo intuyó Cossío, el ejemplo gongorino haya tenido valor desencadenante. En primer lugar adaptaba al género fábula unas técnicas de imitación múltiple que permitían desprenderse de la subordinación a un único texto, y reelaborar el mito en función de un pensamiento propio y actual. En segundo lugar, porque el ritmo lento, regular y sostenido del relato, el modo en que se entrelazan vigorosamente narración y descripción y las constantes figuras que recubren cada motivo conferían al poema un carácter plástico y pictórico, quizá nunca igualado. Esa capacidad de estimular la imaginación visual y de organizar la narración en cuadros apelaba a la emulación de los poetas que compartían el ideal expresado en la fórmula ut pictura poesis, un Jáuregui pintor y crítico de arte, un Lope apasionado por la pintura. Por último, se pretendió emular al Polifemo, porque, gracias al arte de Góngora como al de Marino, la fábula mostraba su carácter propicio al despliegue de un erotismo exaltado que vedaban otros géneros. Esta apertura hacia lo erótico permitía plantear de modo refinado la cuestión de la relación entre el arte y el deseo.

No se nos escapa que precisar y confirmar estas hipótesis requeriría un estudio más profundo y completo. En nuestra estela del Polifemo son figuras estelares -si se nos perdona el juego de palabras- Lope y Jáuregui, lo que no supone ninguna sorpresa, porque, entre los adversarios de Góngora en aquel momento, son los únicos que pretenden encarnar una alternativa seria a su poética, los únicos que no pierden la esperanza de desbancarlo de su papel de adalid de los poetas españoles. Hemos tratado de sugerir que, al responder de modo tradicionalmente ascético a las cuestiones provocadas por el poema de Góngora, contribuyeron a cerrar la vía abierta por éste. De ser así, habrán contribuido a mantener el género en un conformismo ideológico y estético que le vedaba conservar por mucho tiempo su importancia estratégica en la vida de la república literaria. Góngora integraba en su concierto la fiereza y la estridencia, reservaba un lugar a la barbarie en el seno de la más alta cultura. Quizás por ello palidecen frente a él incluso sus más geniales competidores, empeñados en dejar fuera de toda duda, con mayor o menor habilidad, lo selecto de sus gustos y la pureza de sus intenciones. 